\title{
Climate Change and Health
}

\section{Climate change: an emerging health issue}

\section{GUEST EDITORS}

\author{
Anthony G. Capon ${ }^{\mathrm{A}, \mathrm{B}}$ and Elizabeth G. Hanna ${ }^{\mathrm{A}}$ \\ ANational Centre for Epidemiology and Population Health, Australian National University \\ BCorresponding author.Email: tony.capon@anu.edu.au
}

The core concern is succinctly stated: climate change endangers health in fundamental ways.

Dr Margaret Chan, Director-General, World Health Organization on the occasion of World Health Day 2008.

The World Health Organization chose climate change as the theme for last year's World Health Day in an explicit attempt to attract policy-makers to the compelling evidence about the impacts of climate change on health. The reality of humaninduced climate change can no longer be doubted, but the extent of its consequences for health can still be reduced. Consideration of the health impacts of climate change can enable political leaders to act with the required urgency. ${ }^{1}$

Figure 1 illustrates the many ways in which climate change will affect health. ${ }^{2}$ There are likely to be some (modest) positive health consequences from climate change (for example, reduced extreme cold weather events in some locations); however, climate change will mostly have negative impacts on health. Climate change will affect health by changing the frequency and distribution of existing health problems. The health impacts of climate change will be greater in low-income communities; those who have contributed least to climate change will be affected the most. ${ }^{3}$

Climate change is currently high on the public policy agenda in Australia and around the world. A vitally important aspect of climate change policy is the opportunity of cobenefits for health from both mitigation and adaptation actions - examples include eating less meat; using renewable energy sources that reduce air pollution; and active modes of transport. ${ }^{4}$ This positive story is expected to be presented at the United Nations conference on climate change in Copenhagen later in 2009.

\section{Current actions}

The New South Wales (NSW) Government recognises climate change as a serious environmental, economic and social threat. The challenges posed by climate change have informed the NSW Greenhouse Plan, the current State Plan and the forthcoming Climate Action Plan. Box 1 provides a perspective on climate change and the NSW health system.

The Australian Government recently established the National Climate Change Adaptation Research Facility (NCCARF) at Queensland's Griffith University to generate information needed by decision-makers in government, and in vulnerable sectors and communities, to manage the risk of climate change impacts. A National Climate Change Adaptation Research Plan for Human Health has been published..$^{5}$ This plan will inform the work of a research network on this theme (Box 2).

\section{The papers in this issue}

Kjellstrom and Weaver present a succinct overview of climate change and health in Australia. The paper encompasses current and future threats facing Australians, including extreme weather events (storms, floods, heat waves), impacts on worker productivity, water supplies, air quality, vector- and foodborne disease, and impacts on mental health.

There are two papers identifying co-benefits for health from climate change actions. Rissel discusses active travel as an approach to climate change mitigation (reducing carbon dioxide emissions from fossil fuel use in motorised transport) that also has myriad human health benefits. This paper outlines strategies for health and urban planners to increase cycling, and uses Australian examples to illustrate the co-benefits of active travel. Dixon and colleagues focus on 


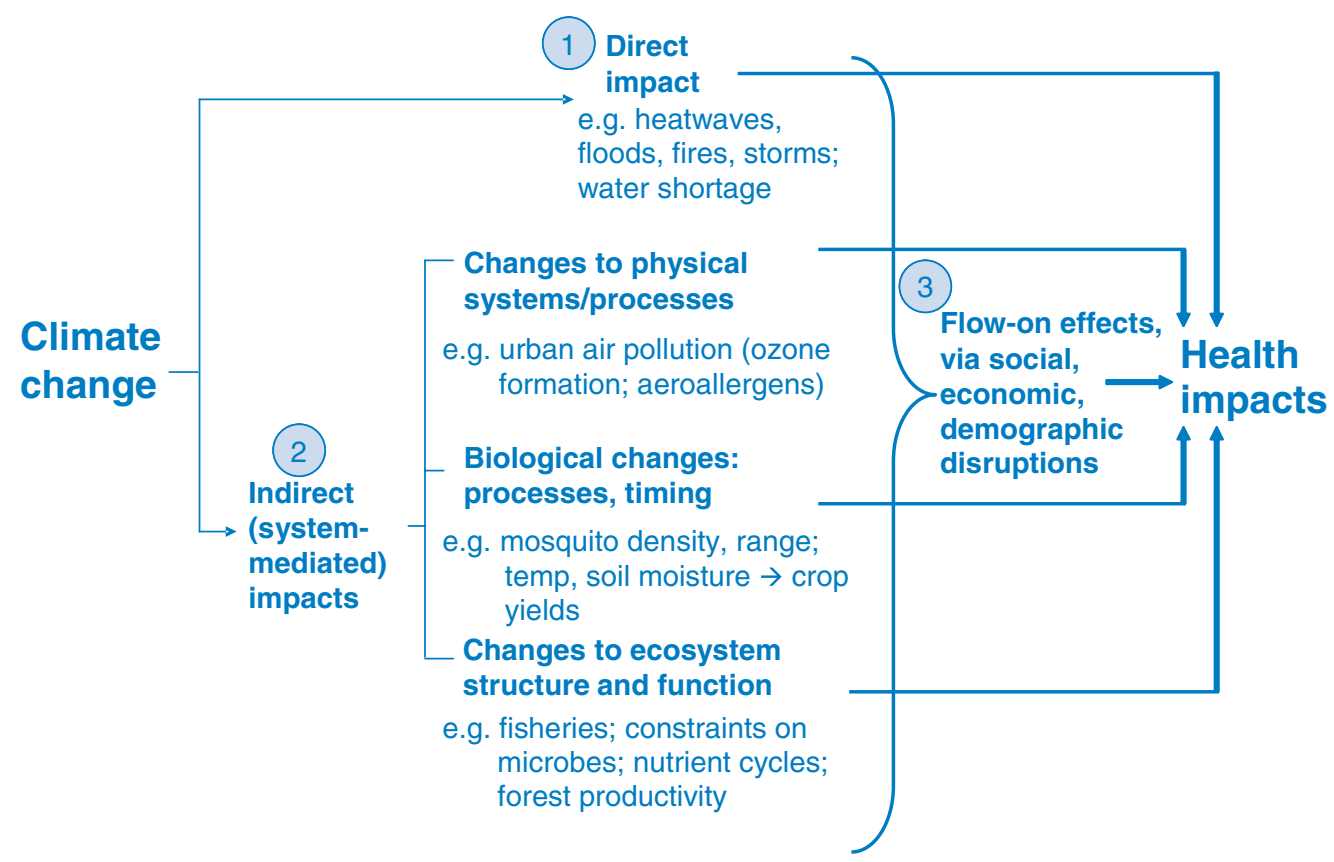

Figure 1. Putative pathways between climate change and health impacts. Used with permission from AJ McMichael.

\section{Box 1. Climate change and the NSW health system}

\section{Adam Craig \\ Environmental Health Branch, NSW Department of Health}

NSW Health is the largest consumer of energy and water of all NSW government agencies and has a commitment to minimise the environmental pollution resulting from the ongoing provision of public health services in NSW. This commitment is articulated in the NSW Government's Sustainability Strategy to reduce greenhouse gas emissions through energy savings and water use.

Developing adaptive responses to the inevitable impacts of climate change on health is another important challenge. Some adaptive strategies will entail revision or extension of existing public health and health planning policies and practices, while others will require innovative actions. Many will require co-ordinated action across components of the health system and by government, industry and community more broadly.

By 2050, NSW is likely to experience an increase in mean maximum and minimum temperatures of $1-3^{\circ} \mathrm{C}$ across the state with most of the change occurring in autumn, winter and spring. NSW will generally be wetter in the warmer months but drier in winter, particularly in the south-west, where a reduction in winter rain of between $20 \%$ and $50 \%$ has been projected. ${ }^{1}$

Environmental changes of this proportion will have both acute and insidious health impacts. For example, more frequent heat waves will result in increased hospital admission for heat-related illness. Changes to the social, economic and cultural fabric of communities, particularly in rural areas, as a result of more frequent and longer lasting droughts will also affect the mental health burden in those communities. ${ }^{2}$ The flow-on impacts on infrastructure management and health service provision are yet to be accurately quantified; nevertheless, it does suggest that significant planning and adaptation will be required.

In NSW, the Department of Environment and Climate Change (DECC) is the lead agency for responding to climate change. NSW Health has been working with DECC through the Greenhouse Innovation Fund to develop a range of adaptation initiatives.

These include:

- The development and testing of a public health heat response plan by Northern Sydney Central Coast Area Health Service in 2007.

- The development, implementation and evaluation of a range of targeted heat health messages by Greater Southern Area Health Service.

- North Coast Area Health Service is harnessing the opportunities offered by climate change mitigation and adaptation to promote healthy lifestyle behaviours - increased physical activity, healthy diets and social connectedness.

The focus of NSW Health's climate change adaptation activity in 2009 will be heat-related illness adaptation, regional health vulnerability assessment and regional adaptation planning.

\section{References}

1. New South Wales Government Department of Environment and Climate Change. Regional Climate Change Impacts. Available from: http://www.environment.nsw.gov.au/climateChange/regionsummary.htm [Updated 20 November 2008; Cited 12 December 2008]

2. Sartore GM, Kelly B, Stain HJ. Drought and its effect on mental health: how GPs can help. Aust Fam Physician 2007; 36: 990-3. 


\title{
Box 2. National Climate Change Adaptation Research Network - human health
}

This network was recently established to improve Australian knowledge about climate change adaptation and human health to enable decision-making by government, industry and communities. The objectives of the network are to:

- foster interdisciplinary research and emerging research methods (time-series methods, spatial analysis, systems-based modelling of complex ecological relationships and processes and scenario-based modelling of future health risks);

- build research and decision-making capacity by mentoring and support for early and mid-career researchers and policymakers;

- facilitate collaboration between researchers, policymakers and practitioners, including involvement across the research cycle (scoping, planning, analysis, reporting); and

- communicate research findings in ways relevant to different sectors and varying regional conditions to strengthen Australia's capacity to anticipate, adapt to and mitigate the human health consequences of climate change.

The Australian National University is the Network host. Further information is available from:

http://www.nccarf. edu.au/?q=node/24

\section{Box 3. Glossary*}

\begin{abstract}
Adaptation
Initiatives and measures to reduce the vulnerability of natural and human systems against actual or expected climate change effects. Various types of adaptation exist, for example, anticipatory and reactive, private and public and autonomous and planned. Examples include heat wave early warning systems and growing more vegetation in cities to reduce the urban heat island.

\section{Adaptive capacity}

The capabilities, resources and institutions of a country, region or individual to implement effective adaptation measures.

\section{Co-benefits}

The benefits of policies implemented for various reasons at the same time, acknowledging that most policies designed to address greenhouse gas mitigation have other, often at least equally important, rationales (e.g. related to objectives of development, sustainability, equity and health).
\end{abstract}

\section{Extreme weather event}

A weather event that is rare at a particular place and time of year. Definitions of rare vary, but an extreme weather event would normally be as rare as or rarer than the 10th or 90th percentile of the observed probability density function. By definition, the characteristics of what is called extreme weather may vary from place to place in an absolute sense. Single extreme events cannot be simply and directly attributed to anthropogenic climate change, as there is always a finite chance the event in question might have occurred naturally.

\section{Greenhouse gas (GHG)}

Greenhouse gases are those gaseous constituents of the atmosphere, both natural and anthropogenic, that absorb and emit radiation at specific wavelengths within the spectrum of thermal infrared radiation emitted by the Earth's surface, the atmosphere itself, and by clouds. This property causes the greenhouse effect. Water vapour $\left(\mathrm{H}_{2} \mathrm{O}\right)$, carbon dioxide $\left(\mathrm{CO}_{2}\right)$, nitrous oxide $\left(\mathrm{N}_{2} \mathrm{O}\right)$, methane $\left(\mathrm{CH}_{4}\right)$ and ozone $\left(\mathrm{O}_{3}\right)$ are the primary greenhouse gases in the Earth's atmosphere.

\section{Mitigation}

Technological change and substitution that reduce resource inputs and emissions per unit of output. Although several social, economic and technological policies would produce an emission reduction, with respect to climate change, mitigation means implementing policies to reduce greenhouse gas emissions and enhance sinks.

\section{Resilience}

The ability of a social or ecological system to absorb disturbances while retaining the same basic structure and ways of functioning, the capacity for self-organisation, and the capacity to adapt to stress and change.

\section{Vulnerability}

The degree to which a system is susceptible to, and unable to cope with, adverse effects of climate change, including climate variability and extremes. Vulnerability is a function of the character, magnitude and rate of climate change and variation to which a system or individual is exposed as well as its sensitivity and its adaptive capacity.

*Source: Climate Change 2007: Synthesis Report. Contribution of Working Groups I, II and III to the Fourth Assessment Report of the Intergovernmental Panel on Climate Change [Core Writing Team, Pachauri, R.K. and Reisinger, A. (eds.)]. Geneva: IPCC; 2007.

co-benefits in the food system, examining the link between industrial food production and food problems such as diets poor in nutrients and loss of control over food choices. Climate change threatens further food shortages. The authors explain why promoting urban agriculture is sustainable and brings multiple health and environmental benefits.

Prolonged droughts over recent years in Australia have exacerbated bushfires and in 2003 NSW and Victoria 
experienced major bushfires and widespread smoke pollution. Kolbe and Gilchrist evaluate the effectiveness of public health advisories about bushfire smoke pollution provided to Albury residents in the summer of 2003.

In the concluding paper, Capon and colleagues argue for systems approaches in governance to address climate change. They argue for a focus on the underlying causes of problems such as climate change and the obesity epidemic. Effective governance will necessitate moving beyond 'silo' approaches to integrative policy and planning.

Climate change, an environmental health issue of unprecedented scale and complexity, necessitates new ways of thinking, communicating and acting for public health. ${ }^{4} \mathrm{We}$ hope this special issue of the Bulletin will encourage public health workers to take on these challenges.

Box 3 contains a glossary of terms used in this issue that may be unfamiliar to Bulletin readers.

\section{References}

1. World Health Organization. Protecting health from climate change - World Health Day 2008. Geneva: WHO, 2008.

2. McMichael AJ, Woodruff RE, Hales S. Climate change and human health: Present and future risks. Lancet 2006; 367 : 859-69. doi:10.1016/S0140-6736(06)68079-3

3. St. Louis ME, Hess JJ. Climate change: impacts on and implications for global health. Am J Prev Med 2008; 35: 527-38. doi:10.1016/j.amepre.2008.08.023

4. Frumkin H, McMichael AJ. Climate change and public health: Thinking, communicating, acting. Am J Prev Med 2008; 35: 403-10. doi:10.1016/j.amepre.2008.08.019

5. National Climate Change Adaptation Research Facility. Human health and climate change: National adaptation research plan. Available from: http://www.nccarf.edu.au/?q=node/42 (Cited 12 December 2008) 


\section{Climate change and health: impacts, vulnerability, adaptation and mitigation}

\author{
Tord Kjellstrom ${ }^{\mathrm{A}, \mathrm{B}}$ and Haylee J. Weaver ${ }^{\mathrm{A}}$ \\ ${ }^{\mathrm{A} N a t i o n a l ~ C e n t r e ~ f o r ~ E p i d e m i o l o g y ~ a n d ~ P o p u l a t i o n ~ H e a l t h, ~}$ \\ Australian National University \\ ${ }^{\mathrm{B} C o r r e s p o n d i n g ~ a u t h o r . ~ E m a i l: ~ k j e l l s t r o m t @ y a h o o . c o m ~}$
}

\begin{abstract}
Global climate change is progressing and health impacts have been observed in a number of countries, including Australia. The main health impacts will be due to direct heat exposure, extreme weather, air pollution, reduced local food production, food- and vectorborne infectious diseases and mental stress. The issue is one of major public health importance. Adaptation to reduce the effects of climate change involves many different sectors to minimise negative health outcomes. Wide-scale mitigation is also required, in order to reduce the effects of climate change. In addition, future urban design must be modified to mitigate and adapt to the effects of climate change. Strategies for mitigation and adaptation can create co-benefits for both individual and community health, by reducing non-climate-related health hazard exposures and by encouraging health promoting behaviours and lifestyles.
\end{abstract}

Since 1950, average land temperatures in Australia have risen by $0.9^{\circ} \mathrm{C} .{ }^{1} \mathrm{~A}$ decline in rainfall has been observed for much of eastern and south-western Australia, whereas north-western Australia has experienced wetter summers. ${ }^{1}$ Globally, the trend of climatic variability is similar. ${ }^{2}$

The process will continue with a projected average global temperature increase of 1.8 to $4.0^{\circ} \mathrm{C}$ (average $3^{\circ} \mathrm{C}$ ) by 2100 depending on actions taken to limit greenhouse gas (GHG) emissions and scenarios for future development. ${ }^{2}$ Rainfall is likely to become more variable and there will be more extreme weather with storms, floods and droughts. ${ }^{2}$ By 2030 the average temperature in Australia may increase by $1^{\circ} \mathrm{C}$, and by 2070 , it may have increased by $1.8^{\circ} \mathrm{C} .{ }^{1}$ Decreases in rainfall are predicted for southern areas in winter, and for eastern areas in spring, while Australian average rainfall may not change. ${ }^{1}$ It is essential that the Australian community is adequately prepared for any health consequences of climate change. ${ }^{3}$

\section{Adaptation and mitigation}

Australia has diverse environments including alpine, temperate, tropical and desert. There are numerous low population density rural areas and highly populated cities. The possible health impacts of climate change for people living in each type of area need to be considered when developing strategies to manage climate change.

The aim of mitigation is to reduce anthropogenic GHG emissions and other causes of climate change, for instance, by increasing electricity generated from renewable sources (hydro-electric, solar and wind energy) and reducing motor vehicle use. In addition, reduction of meat consumption is considered a mitigation strategy, due to the energy-intensive methods of modern farming and methane emissions from cows and sheep. ${ }^{4}$ Mitigation strategies are often integrated into planning and infrastructure by local councils and state and federal governments; however, individuals can also participate on a small scale by reducing unnecessary energy consumption and using cars less frequently.

Adaptation means modifying current policy and practice to cope with unavoidable changes in climate. Governments need to implement community-wide adaptation plans, while individuals can act in a number of ways; for example, by staying in the shade while outside, or installing ceiling fans to reduce the risk of direct heat effects. ${ }^{5}$ Mitigation and adaptation strategies can have cobenefits for health. For example, a reduction in car use reduces GHGs as well as decreasing crash injuries, air pollution and traffic noise and increasing personal physical activity and fitness levels. ${ }^{6}$

\section{Coping with health impacts of climate change in Australia}

The expected changes in the climate may lead to several types of increased mortality and morbidity, including temperature-related illness and death, extreme weather effects, air pollution effects, water and food-related diseases, vectorborne diseases, effects of food and water 
shortages and effects of population displacement. ${ }^{7,8}$ Although the most severe health impacts are expected in low income countries, Australia will not be spared (see for example, http://www.environment.nsw.gov.au/ climatechange/health.htm). ${ }^{7-9}$ The people most vulnerable to the effects of climate change are children, elderly people, Indigenous communities and people with preexisting diseases and disabilities.

\section{Environmental disasters, storms and floods}

Storms, droughts and other climatic disasters are likely to increase in intensity and frequency (albeit with regional variation). ${ }^{10}$ Regional, targeted preparation plans for the health sector are therefore necessary. Tropical cyclones and other storms will cause injuries and flooding due to storm surges and severe downpours. ${ }^{11}$ Storms create the risk of drowning and health risks from damaged water supplies, sewage pipes, loss of electricity and contaminated food. The harmful effects of storms were demonstrated in the Hunter region of New South Wales (NSW) in 2007.12 Problems with water and sewerage supply and quality were experienced because pumps failed. Food was spoiled as it could not be cooked properly or kept cool in refrigerators, due to problems with electricity supply. ${ }^{12}$ Floods can also lead to increased infectious and vectorborne diseases. ${ }^{13}$ Adaptation to storms requires preventive steps, including timely storm warnings and long-term seasonal modelling of the future frequency of storms.

\section{Extreme heat exposure}

Heat waves can dramatically increase mortality as seen in France in 2003. ${ }^{14}$ For Australia, models project more hot days (temperatures greater than 35 to $40^{\circ} \mathrm{C}$ ) by 2070 , while the frequency of cold spells will decrease. ${ }^{1}$ Heat exposure causes morbidity and mortality, particularly in urban areas due to the heat island effect. ${ }^{15,16}$ Research in five major Australian cities showed that mortality increased at temperatures above $28^{\circ} \mathrm{C}$, particularly among people 65 years or older. ${ }^{17-20}$ In NSW, hospital admissions for heat-related illnesses increased during heat waves. In Adelaide, overall daily mortality has not increased during heat waves, but ambulance emergencies and certain types of hospital admissions (for instance, mental health categories) have increased. ${ }^{21}$ Heat wave warning systems and response plans are needed in addition to housing, workplace and urban design that maximises natural breezes and shade and minimises the heat island effect. ${ }^{20}$

A particular risk in hot weather in Australia is bush fires and related health risks from smoke and burns. ${ }^{22}$ Adaptive strategies for fires involve reducing fire risk by controlled burning of fuel in fire-prone forests and fire warning systems.

\section{Heat stress and workforce productivity}

Heat can cause physiological stress, particularly in people with high levels of physical activity. ${ }^{23}$ Children and elderly people are also vulnerable to heat stress as their physiology is less resilient than that of younger adults and they may be less able to take cooling action in heat waves. ${ }^{24}$ Australian studies have primarily measured exposure and physiological effects in workers with extreme heat exposure, such as fire fighters, mine workers, sheep shearers, and cattle musterers. ${ }^{25-31}$ Direct heat exposure reduces a worker's ability to continuously carry out heavy physical work. International standards recommend adequate rest breaks in hot environments. ${ }^{32-35}$ Heat exposure also limits the ability of people to exercise for leisure and health. ${ }^{36}$

\section{Water quality and quantity}

Intense precipitation events can overload sewers and storm-water drains and flush pathogens from catchment areas into drinking water reservoirs and dams. ${ }^{37}$ Drought can concentrate pollutants in dams, via evaporation, and increased water temperature in dams and lakes can lead to blooms of toxin-producing cyanobacteria. ${ }^{38}$ Modelling can be used to predict pathogen loads in water supplies, which may be a useful tool in managing drinking water supplies in the future, when climate change influences water quality and availabilty. ${ }^{39}$ Desalination plants, and improved water recycling may contribute to water security. Adaptive strategies for reducing water consumption are already in place in most councils and shires in Australia in order to conserve the water currently held in dams.

\section{Air pollution}

Epidemiological studies in Australian cities have documented increased daily mortality and hospital admissions associated with urban air pollution. ${ }^{40,41}$ More ozone is formed from the exhaust emissions of motor vehicles during summer periods of increasing heat in combination with strong sunlight. ${ }^{42}$ During the heat wave in France in 2003, the attributable fractions of daily mortality excess due to heat and ozone exposure were similar. ${ }^{43}$ Many excess deaths may have been caused by ozone and not by heat itself. The effects of particulate matter air pollution in Brisbane have been shown to increase alongside temperature. ${ }^{44} \mathrm{~A}$ reduction in car usage, to reduce emissions of GHGs and other air pollutants such as particulate matter and nitrogen dioxide, is a key mitigation strategy. ${ }^{40}$

Pollen and other aeroallergens, such as mould spores, may be influenced by climate change, increasing asthma risks. ${ }^{45}$ Pollen warnings and individual management of asthma are two adaptive strategies that can reduce respiratory diseases affected by aeroallergens.

\section{Vectorborne infectious diseases}

The potential risk of increased vectorborne disease spread in Australia due to climate change was first discussed a decade ago. ${ }^{46,47}$ Distributions of most arboviruses may alter due to climate change, but those that are highest in prevalence in Australia are Ross River virus (RRV), 
Barmah Forest virus (BFV) and dengue virus. ${ }^{13}$ The distributions of both RRV and BFV are likely to be altered by changes in rainfall, tidal inundation and land-use patterns, which will enable populations of mosquito vectors to establish in new areas. ${ }^{48}$ Under climate change scenarios, it has been predicted that dengue virus may eventually be found as far south as Sydney. ${ }^{49}$ Adaptive strategies for arbovirus control include improved modelling, early warning and control systems for mosquitoes, and ensuring the use of flyscreens in mosquito-prone areas.

\section{Foodborne diseases}

Foodborne diseases, particularly gastroenteritis, are relatively common in Australia. ${ }^{50}$ The symptoms of these diseases are usually mild, but can be serious in vulnerable people, occasionally causing death. ${ }^{51}$ The most common pathogens in food are Campylobacter and Salmonella and the notification rate is related to monthly temperature indicating a potential effect of climate change. ${ }^{52}$ In addition, Staphylococcus aureus is a common bacterium on skin that can grow in food, producing a powerful toxin that causes diarrhoea and vomiting. The growth and spread of these pathogens increase if the storage temperature of foods is not sufficiently cold, which is of vital importance in the event of interruptions to electricity supply. ${ }^{51}$ Adaptation strategies include better monitoring of foodborne diseases and increased awareness of health risks.

\section{Community and mental health}

Climate change may lead to adverse mental health outcomes. ${ }^{53}$ Natural disasters, such as storms, cyclones and prolonged drought have been shown to adversely affect mental health over time. ${ }^{54-57}$ In the future, Australia is likely to experience increases in droughts, which have been shown to be associated with an increased rate of suicide. ${ }^{57}$ Increases in individual mental health problems will have a follow-on effect for communities. Therefore, an important adaptive strategy is to increase community resilience to enable individuals to cope better with the conditions created by climate change.

A well-developed health care system in each community is another important adaptive strategy. Whether the health impacts are due to heat, violent weather, air pollution, infectious diseases or mental stress, efficient diagnostic and treatment services will make it possible to minimise the health impacts on the community. Such a system needs to ensure equitable access for all in the community, including the most vulnerable groups. A hotter climate may cause deterioration of medications and pharmaceutical therapies during storage, particularly in remote places with less developed health services. ${ }^{58}$

\section{Health co-benefits of mitigation and adaptation}

Table 1 summarises examples of health co-benefits that can be expected from mitigation and adaptation strategies as a response to climate change. There is a need for further research into the potential effects of different intervention strategies. For certain interventions, the value of health cobenefits may be even greater than the prevented climate change impacts.

\section{Conclusion}

The broad range of likely health impacts of climate change in NSW and Australia means that a variety of methods and strategies should be applied for mitigation and adaptation. Mitigation and adaptation can have direct co-benefits for the health of individuals and communities and should be encouraged. Early warning systems have a range of applications that can be used to assist communities to prepare for adverse conditions and the associated threats to health. Improving response teams and health systems (such as

Table 1. Examples of the main co-benefits of mitigation and adaptive strategies as a response to climate change

\begin{tabular}{|c|c|c|}
\hline Mitigation strategy & Adaptation strategy & Health co-benefits \\
\hline $\begin{array}{l}\text { Decreased fossil fuel } \\
\text { combustion }\end{array}$ & & $\begin{array}{l}\text { Cleaner, smog-free air and less respiratory } \\
\text { and cardiorespiratory diseases }\end{array}$ \\
\hline Improved public transport & & $\begin{array}{l}\text { More people walking (or cycling) to and } \\
\text { from stations, increases active transport, } \\
\text { promotes health and fitness and } \\
\text { reduces obesity }\end{array}$ \\
\hline \multirow{4}{*}{$\begin{array}{l}\text { Increased fruit and } \\
\text { vegetable consumption } \\
\text { and reduced meat } \\
\text { consumption }\end{array}$} & & $\begin{array}{l}\text { Less obesity, lower rates of cancer and } \\
\text { several other diseases }\end{array}$ \\
\hline & $\begin{array}{l}\text { Early warning systems for } \\
\text { weather extremes and disease } \\
\text { outbreaks }\end{array}$ & $\begin{array}{l}\text { Better health protection systems overall, } \\
\text { less impact in normal emergencies }\end{array}$ \\
\hline & Improved food handling practices & Reduced foodborne infections overall \\
\hline & $\begin{array}{l}\text { Improved programs to adapt } \\
\text { rural economies to a } \\
\text { changing climate }\end{array}$ & $\begin{array}{l}\text { Strengthened social capital and beneficial } \\
\text { effects on mental health }\end{array}$ \\
\hline
\end{tabular}


emergency services and health care practitioners) will enable a rapid response to emergency situations. The most important adaptive strategy that can be applied, however, is that of increased community awareness of climate change and the associated health risks. By understanding how environmental changes can result in adverse health impacts, we can plan to minimise exposure and health risks and to cope with the unavoidable effects of climate change.

\section{References}

1. CSIRO. Climate change in Australia. Technical report 2007. Melbourne: CSIRO and Australian Bureau of Meteorology; 2007.

2. IPCC. 2007: Climate Change 2007: Synthesis Report. Contribution of Working Groups I, II and III to the Fourth Assessment Report of the Intergovernmental Panel on Climate Change. IPCC, Geneva, Switzerland. Available from: http://www.ipcc.ch/ipccreports/ar4-syr.htm (Cited 02 December 2008.)

3. Preston BL, Jones RN. Climate change impacts on Australia and the benefits of early action to reduce global greenhouse gas emissions. Melbourne: CSIRO; 2006.

4. McMichael AJ, Powles JW, Butler CD, Uauy R. Food, livestock production, energy, climate change, and health. Lancet 2007; 370: 1253-63. doi:10.1016/S0140-6736(07)61256-2

5. Mukheibir P, Ziervogel G. Developing a Municipal Adaptation Plan for climate change: the city of Cape Town. Environ Urban 2007; 19: 143-58. doi:10.1177/0956247807076912

6. Kjellstrom T, van Kerkhoff L, Bammer G, McMichael AJ. Comparative assessment of transport risks - how it can contribute to health impact assessment of transport policies. Bull World Health Organ 2003; 81: 451-7.

7. McMichael AJ, Campbell-Lendrum D, Kovats S, Edwards S, Wilkinson P, Wilson T et al. Global climate change. In: Ezzati M, Lopez AD, Rodgers A, Murrgay CJL, editors. Comparative quantification of health risks: global regional burden of diseases due to selected major risk factors. Vol. 2. Chapter 20. Geneva: World Health Organization; 2004. pp. 1543-649.

8. Patz JA, Gibbs HK, Foley JA, Rogers JV, Smith KR. Climate change and global health: quantifying a growing ethical crisis. EcoHealth 2007; 4: 397-405. doi:10.1007/s10393-007-0141-1

9. Bambrick H, Dear K, Woodruff R, Hanigan I, McMichael AJ. The impact of climate change on three health outcomes: Temperature-related mortality and hospitalisations, salmonellosis and other bacterial gastroenteritis, and population at risk from dengue. Commissioned report for the Garnaut Climate Change Review. Canberra: The Australian National University; 2007.

10. Kirch W, Menne B, Bertollini R. Extreme weather events and public health responses. Berlin: Springer; 2005.

11. McMichael AJ, Woodruff RE, Whetton P, Hennessy K, Nicholls N, Hales S et al. Human health and climate change in Oceania: a risk assessment 2002. Canberra: Commonwealth Department of Health and Ageing; 2003.

12. Cretikos MA, Merritt TD, Main K, Eastwood K, Winn L, Moran L et al. Mitigating the health impacts of natural disaster - the June 2007 long-weekend storm in the Hunter region of New South Wales. Med J Aust 2007; 187: 670-3.
13. McMichael AJ, Weaver HJ, Berry H, Beggs PJ, Currie B, Higgins J et al. National Adaptation Research Plan (Human Health). Commissioned report by the Australian Department of Health and Ageing, 2008.

14. Poumadere M, Mays C, Le Mer S, Blong R. The 2003 heat wave in France: Dangerous climate change here and now. Risk Anal 2005; 25: 1483-94. doi:10.1111/j.15396924.2005.00694.x

15. Kovats RS, Hajat $\mathrm{S}$. Heat stress and public health: a critical review. Ann Rev Public Health 2008; 29: 41-51. doi:10.1146/annurev.publhealth.29.020907.090843

16. Haines A, Kovats RS, Campbell-Lendrum D, Corvalan C. Climate change and human health: impacts, vulnerability and mitigation. Lancet 2006; 367(9528): 2101-9. doi:10.1016/S0140-6736(06)68933-2

17. Guest CS, Willson K, Woodward AJ, Hennessy K, Kalkstein LS, Skinner C et al. Climate and mortality in Australia: retrospective study, 1979-1990, and predicted impacts in five major cities in 2030. Clim Res 1999; 13: 1-15. doi:10.3354/cr013001

18. Vaneckova P, Hart MA, Beggs PJ, de Dear RJ. Synoptic analysis of heat-related mortality in Sydney, Australia, 1993-2001. Int J Biometeorol 2008; 52(6): 439-51. doi:10.1007/s00484-007-0138-z

19. Bi P, Parton KA, Wang J, Donald K. Temperature and direct effects on population health in Brisbane, 1986-1995. J Environ Health 2008; 70: 48-53.

20. Nicholls N, Skinner C, Loughnan M, Tapper N. A simple heat alert system for Melbourne, Australia. Int J Biometeorol 2008; 52: 375-84. doi:10.1007/s00484-007-0132-5

21. Nitschke M, Tucker GR, Bi P. Morbidity and mortality during heatwaves in metropolitan Adelaide. Med J Aust 2007; 187: $662-5$.

22. Hennessy K, Lucas C, Nicholls N, Bathols J, Suppiah R, Ricketts J. Climate change impacts on fire-weather in southeast Australia. Melbourne: CSIRO; 2005.

23. Taylor NAS. Challenges to temperature regulation when working in hot environments. Ind Health 2006; 44: 331-44. doi:10.2486/indhealth.44.331

24. Parsons K. Human thermal environments. 2nd ed. London: Taylor and Francis; 2003.

25. Budd GM, Brotherhood JR, Hendrie AL, Jeffery SE, Beasley FA, Costin BP et al. Project Aquarius 10. Effects of work, weather and fire on the energy expenditure, strain and productivity of men suppressing wildland fires. Int J Wildland Fire 1997; 7: 167-80. doi:10.1071/WF9970167

26. Donoghue A, Sinclair M, Bates G. Heat exhaustion in a deep underground metalliferous mine. Occup Environ Med 2000; 57: 165-74. doi:10.1136/oem.57.3.165

27. Miller VS, Bates GP. The thermal work limit is a simple reliable heat index for the protection of workers in thermally stressful environments. Ann Occup Hyg 2007; 51: 553-61. doi:10.1093/annhyg/mem035

28. Carter A, Muller R. Hydration knowledge, behaviours and status of staff at the residential camp of a fly-in/fly-out minerals extraction and processing operation in tropical North-Eastern Australia. Ind Health 2007; 45: 579-89. doi:10.2486/indhealth.45.579 
29. Muller R, Carter A, Williamson A. Epidemiological diagnosis of occupational fatigue in a fly-in/fly-out operation of the mineral industry. Ann Occup Hyg 2008; 52: 63-72. doi:10.1093/annhyg/mem058

30. Gun RT, Budd GM. Effects of thermal, personal and behavioural factors on the physiological strain, thermal comfort and productivity of Australian shearers in hot weather. Ergonomics 1995; 38: 1368-84. doi:10.1080/00140139508925195

31. Taylor NAS, Caldwell JN. The impact of protective helmets on physiological strain and cognitive function during horseback mustering. Sydney: Meat and Livestock Australia; 2007.

32. Budd GM. Wet-bulb globe temperature (WBGT) - its history and limitations. J Sci Med Sport 2008; 11: 20-32. doi:10.1016/j.jsams.2007.07.003

33. International Standards Organization. Hot environments Estimation of the heat stress on working man, based on the WBGT-index (wet bulb globe temperature). ISO Standard 7243. Geneva: International Standards Organization; 1989.

34. Kjellstrom T. Climate change, heat exposure and labour productivity. Epidemiology 2000; 11: S144.

35. Kjellstrom T, Dirks KN. Heat stress and ability to work in the context of climate change. Proceedings of the International Thermal Physiology Symposium; 2001 Sep 2-6; Wollongong: University of Wollongong; 2001. Available from: http://www.apps.org.au/Proceedings/32(2)Suppl.1/23P/ 23P.pdf (Cited 11 December 2008.)

36. American Academy of Pediatrics, Committee on Sports Medicine and Fitness. Climatic heat stress and the exercising child and adolescent. Pediatrics 2000; 106: 158-9. doi:10.1542/peds.106.1.158

37. Thomas KM, Charron DF, Waltner-Toews D, Schuster C, Maarouf AR, Holt JD. A role of high impact weather events in waterborne disease outbreaks in Canada, 1975-2001. Int $J$ Environ Health Res 2006; 16(3): 167-80. doi:10.1080/09603120600641326

38. Hunter PR. Climate change and waterborne and vector-borne disease. J Appl Microbiol 2003; 94: S37-46. doi:10.1046/j.1365-2672.94.s1.5.x

39. Ferguson CM, Croke BFW, Beatson PJ, Ashbolt NJ, Deere DA. Development of a process-based model to predict pathogen budgets for the Sydney drinking water catchment. $J$ Water Health 2007; 5: 187-208. doi:10.2166/wh.2006.050

40. Kjellstrom T, Neller A, Simpson R. Air pollution and its health impacts: the changing panorama. Med J Aust 2002; 177: 604-8.

41. Simpson RW, Chan YC, Hansen CA, Jalaludin B, Morgan G, Barnett AG et al. Several references on epidemiological studies of air pollution in Australia 2008. Available from: http://research.usc.edu.au/vital/access/manager/Repository? expert $=$ creator $\% 3 \mathrm{a} \% 22$ Simpson $\% 2 \mathrm{c}+\mathrm{R}+\mathrm{W} \% 22$ (Cited 02 December 2008.)

42. Duffy BL, Nelson PF, Ye Y, Weeks IA. Speciated hydrocarbon profiles and calculated reactivities of exhaust and evaporative emissions from 82 in-use light-duty Australian vehicles. Atmos Environ 1999; 33: 291-307. doi:10.1016/S13522310(98)00163-0

43. Dear K, Ranmuthugala G, Kjellstrom T, Skinner C, Hanigan I. Effects of temperature and ozone on daily mortality during the
August 2003 heat wave in France. Arch Environ Occup Health 2005; 60: 205-12. doi:10.3200/AEOH.60.4.205-212

44. Ren C, Tong S. Temperature modifies the health effects of particulate matter in Brisbane, Australia. Int J Biometeorol 2006; 51: 87-96. doi:10.1007/s00484-006-0054-7

45. Beggs PJ. Impacts of climate change on aeroallergens: past and future. Clin Exp Allergy 2004; 34: 1507-13. doi:10.1111/j.1365-2222.2004.02061.x

46. Russell RC. Mosquito-borne arboviruses in Australia: the current scene and implications of climate change for human health. Int J Parasitol 1998; 28(6): 955-69. doi:10.1016/S0020-7519(98)00053-8

47. Sutherst RW. Implications of global change and climate variability for vector-borne diseases: generic approaches to impact assessments. Int J Parasitol 1998; 28: 935-45. doi:10.1016/S0020-7519(98)00056-3

48. Jacups SP, Whelan PI, Currie BJ. Ross River virus and Barmah Forest virus infections: a review of history, ecology and predictive models, with implications for tropical northern Australia. Vector Borne Zoonotic Dis 2008; 8(2): 283-97. doi:10.1089/vbz.2007.0152

49. Hales S, de Wet N, Maindonald J, Woodward A. Potential effect of population and climate changes on global distribution of dengue fever: an empirical model. Lancet 2002; 360(9336): 830-4. doi:10.1016/S0140-6736(02)09964-6

50. Hall GV, Kirk MD, Ashbolt R, Stafford R, Lalor K. OzFoodNet Working Group. Frequency of infectious gastrointestinal illness in Australia, 2002: regional, seasonal and demographic variation. Epidemiol Infect 2006; 134: 111-8. doi:10.1017/S0950268805004656

51. Hall GV, D'Souza RM, Kirk MD. Foodborne disease in the new millennium: out of the frying pan and into the fire? Med J Aust 2002; 177: 614-8.

52. D'Souza RM, Becker NG, Hall G, Moodie KBA. Does temperature affect foodborne disease? Epidemiology 2004; 15: 86-92. doi:10.1097/01.ede.0000101021.03453.3e

53. Berry HL, Kelly BJ, Hanigan IC, Coates JH, McMichael AJ, Welsh JA et al. Rural mental health impacts of climate change. Commissioned report for the Garnaut Climate Change Review. Canberra: The Australian National University; 2008.

54. Raphael B. When disaster strikes: How individuals and communities cope with catastrophe. New York: Basic Books; 1986.

55. McFarlane A, Clayer J, Brookless C. Psychiatric morbidity following a natural disaster: an Australian bushfire. Soc Psychiatry Psychiatr Epidemiol 1997; 32(5): 261-8. doi:10.1007/BF00789038

56. Sartore G, Hoolahan B, Tonna A, Kelly B, Stain H. Wisdom from the drought: Recommendations from a consultative conference. Aust J Rural Health 2005; 13(5): 315-20. doi:10.1111/j.1440-1584.2005.00723.x

57. Nicholls N, Butlere CD, Hanigan I. Inter-annual rainfall variations and suicide in New South Wales, Australia, 1964-2001. Int J Biometeorol 2006; 50: 139-43. doi:10.1007/s00484-005-0002-y

58. Beggs PJ. Impacts of climate and climate change on medications and human health. Aust N Z J Public Health 2000; 24: 630-2. doi:10.1111/j.1467-842X.2000.tb00531.x 


\section{Active travel: a climate change mitigation strategy with co-benefits for health}

\section{Chris E. Rissel}

Health Promotion Service, Sydney South West Area Health Service School of Public Health, University of Sydney

Email: criss@email.cs.nsw.gov.au

\begin{abstract}
Reducing the burning of fossil fuels for transport will help reduce the rate of climate change and the severity of the impact of climate change. The alternatives to private motor vehicles include active travel modes such as walking, cycling and use of public transport. While simultaneously reducing carbon dioxide emissions and traffic congestion, active transport leads to increased levels of physical activity and social interaction. This article summarises a number of NSW active travel initiatives. Despite some positive steps in NSW, other Australian states have invested far more and can demonstrate greater changes in travel behaviour.
\end{abstract}

New South Wales (NSW) per capita greenhouse gas emissions are in the order of 23 tonnes per person each year, which is more than double that of the United Kingdom, Germany and Japan (with emissions at just over 10 tonnes per person) and almost double the average for industrialised nations (about 13 tonnes). ${ }^{1}$ Transport emissions include those from road (cars, buses and trucks), rail, shipping and aviation for both passengers and freight, and represent the second largest source of emissions $(14 \%){ }^{2}$

Reducing the burning of fossil fuels for transport will help reduce the rate of climate change and the severity of the impact of climate change. A number of factors are now simultaneously contributing to higher oil and petrol prices, which are likely to have the effect of reducing the consumption of fossil fuels for transport. If Australian government policy introduces an emissions trading scheme that includes transport, the price of (carbon-based) petrol will increase.

Even greater increases in price will come from oil supply crises (e.g. natural disasters such as Hurricane Katrina, or threats to the oil supply from terrorists). Ultimately, demand for oil will exceed supply (which is finite) as the economies of China and India continue to grow. This situation is likely within our lifetime. ${ }^{3-5}$ Already Australians are looking at the cost of driving motor vehicles and thinking about driving less, and the shift away from cars is expected to become more pronounced as petrol prices inevitably rise and concern about climate change increases.

\section{Transport is a social determinant of health}

Although transport is not a traditional focus for health services, it is recognised internationally as a social determinant of health. ${ }^{6}$ As well as being a source of greenhouse gas emissions and other air pollutants, the transport system contributes to injury rates and congestion, and affects access to services and social activities. As transport costs increase, transport and transport availability will increasingly be an issue of equity. Transport deserts areas without reasonable access to public transport - have already been identified in parts of western Sydney, and people living in such areas will be increasingly disadvantaged. ${ }^{7}$ People who cannot afford to drive will need other transport options, such as public transport and bicycle paths. It will be the responsibility of government to ensure that this infrastructure is provided. As Enrique Peñalosa, former mayor of Bogata, Colombia, said, 'A safe cycle path is a symbol of democracy; it shows that a person on a $\$ 40$ bicycle is as important as a person in a $\$ 40000$ car' (personal communication, July 2008).

The alternatives to private motor vehicle-oriented transport include active travel modes such as walking, cycling and use of public transport, either for the whole or part of journeys. While simultaneously reducing carbon dioxide emissions and traffic congestion, active travel leads to increased levels of physical activity, reduced exposure to pollutants (air and noise) and increased social interaction. While the concept of active travel is quite simple, people will default to current practice (i.e. use of the private motor vehicle) unless the alternative travel modes are uncomplicated, safe, easy, affordable and convenient. Active travel is more difficult in settings where there is no or infrequent public transport, or where distances make the time and distance barrier too great to make cycling or walking feasible, as is the case in some outer urban and rural settings. 


\section{NSW initiatives}

In NSW there are a number of initiatives that seek to increase active travel. While these initiatives are usually designed initially to increase physical activity levels, they also have the added benefit of mitigation of climate change. This outcome is in contrast to many other initiatives that represent adaptation and response to climate change (e.g. responding to severe weather events).

In NSW, the Premier's Council for Active Living involves a number of relevant agencies in high level discussions and collaboration. ${ }^{8}$ The role of the Council is to "provide leadership and advice to the Premier to encourage more people to be more active more often' by working collaboratively with senior representatives from government, industry and community sector. Projects tend to be of statewide significance, and include:

- work with a developer to incorporate active living design considerations in new housing developments

- incorporation of active living physical environment characteristics into Metrix, a proposed tool that the Department of Planning is developing to evaluate local councils' local environmental plans

- input into the urban design code for new housing release areas

- work with the NSW State Property Authority to incorporate end-of-trip facilities (such as secure bicycle parking, showers and change rooms) within refurbished buildings when government agencies relocate

- co-ordination of a new whole-of-NSW government Bicycle Plan

- co-ordination of a high level government agency active transport roundtable.

Specific government agencies have also developed guidelines for planners and engineers responsible for building the urban environment that can positively or negatively influence physical activity and active travel. ${ }^{9}$ The former NSW Department of Infrastructure, Planning and Natural Resources in conjunction with the Roads and Traffic Authority (RTA) developed planning guidelines for walking and cycling, and the RTA runs training programs for local government engineers, who are in a position to apply these guidelines to the building of specific local environments. ${ }^{10}$ The RTA also conducts free courses in how to prepare transport access guides. Other agencies such as the National Heart Foundation of Australia have also produced similar documents that highlight the benefits of designing urban environments to facilitate walking and cycling. ${ }^{11}$

\section{Sydney South West Area Health Service initiatives}

There are many examples of local programs that promote active travel. The Sydney South West Area Health Service (SSWAHS) has implemented a number of programs over the last decade. One such program was a health service worksite program involving social marketing and an individual travel behaviour change program that led to modest changes in driving to work and reduced car travel on weekends. ${ }^{12}$ Another strategy has been the development of transport access guides for major trip generators such as hospitals. ${ }^{13}$ These guides illustrate how to travel to and from the hospitals through active travel by showing where the locations of cycle paths, recommended walking routes from rail stations and bus stops (including an indication of the frequency of buses). By not showing parking stations and making active travel easier, this strategy is intended to influence the decision of how to travel to these specific destinations.

An innovative research program underway in SSWAHS is promoting cycling in two local government areas (with a third as a comparison area). The Cycling Connecting Communities project will test whether promoting the use of cycling infrastructure such as new cycle paths in the Fairfield and Liverpool areas will increase overall levels of physical activity in the community. ${ }^{14}$ It will focus on adults, and particularly those people who do not currently ride bicycles, with a wide range of strategies. This project continues earlier cycling promotion work involving the development of a cycling proficiency course to increase the skills and confidence of people wanting to ride more, and the development of a staff bicycle pool. ${ }^{15,16}$

Two other programs in SSWAHS have focused on active travel to school. One is the Central Sydney Walk to School Trial, involving 24 primary schools in the inner west of Sydney and the other is the NSW TravelSmart Schools Program involving 15 primary schools in the inner west and eastern suburbs of Sydney. ${ }^{17,18}$ Both programs had a modest influence on travel behaviour, and highlighted that it is the parent journey to work that is a key factor that influences parents' decisions on how they and their children travel to and from school. ${ }^{19}$ Interestingly, most of the walk-to-school programs internationally have had small effects. In contrast, a well-funded program in California sought to change the physical environment around schools and the main routes to schools. ${ }^{20}$ This program is probably the most successful of any in the world in increasing the number of children actively travelling to school.

With cycling the lowest of the active travel modes, there is considerable potential to increase the proportion of trips by bicycle. Cycling is the fourth most popular form of recreational sport or exercise in Australia, and the Australian Bureau of Statistics census indicates that the journey to work by bicycle has consistently increased over the last decade, with a $22 \%$ increase across Australia from 2001 to 2006..$^{21,22}$ Almost half (42\%) of all households in Sydney in 2005 had a bicycle and new bicycles have consistently outsold new cars for each of the last eight years in Australia. ${ }^{23,24}$

\section{Investment in cycling produces outcomes}

Despite some positive steps towards a greater emphasis on active transport in NSW, other Australian states have 
invested far more and can demonstrate greater changes in travel behaviour. For example, investment in cycling infrastructure over the last decade in Melbourne (up to $\$ 13$ million per annum) has led to increases in cycling from 2001 to 2006 of $42 \% .^{22,25}$ In comparison, cycling in Sydney has increased only 9\%, with the RTA spending \$7 million across NSW in 2006-07 (see Table 1). ${ }^{26}$ The city of London, as part of their Climate Action Plan, has increased funding for cycling and walking by almost five-fold - from $£ 13$ million a year in 2003-04 to £62 million in 2008-09. ${ }^{27}$

Analysis of the 1980 to 1987 Fremantle Network Bike Plan found that it was a worthwhile economic investment for the community, with a $12 \%$ annual increase in the cycling population resulting in transport and health savings to that community of $\$ 420000$ per annum, compared to the implementation costs of the bike plan of $\$ 273000$ per annum. ${ }^{28}$ In addition to social and environmental benefits, there was a benefit-to-cost ratio, in economic terms alone, of $1.46: 1 .{ }^{28}$

A recent review of transport and health promotion interventions to increase levels of cycling found that, despite varying levels of research rigour, most programs did lead to a positive increase in cycling. ${ }^{29}$ An investment in infrastructure for cycling and social and behavioural programs

Table 1. Investment in cycling* and change in cycling usage for journeys to work by Australian capital cities, 2001 to 2006

\begin{tabular}{|c|c|c|}
\hline & $\begin{array}{l}\text { Annual investment } \\
\text { in cycling }\left(\${ }^{\prime} 000 \mathrm{~s}\right)^{*}\end{array}$ & $\begin{array}{l}\text { Journey to work by } \\
\text { bicycle - ABS data } \\
\text { (\% change } 2001 \\
\text { to 2006) }\end{array}$ \\
\hline Sydney & $7000^{* * a}$ & 9 \\
\hline Melbourne & $13000^{b}$ & 43 \\
\hline Adelaide & $3450^{* * b}$ & 31 \\
\hline Hobart & $750^{* * \mathrm{~b}}$ & 25 \\
\hline Perth & $9750^{b}$ & 16 \\
\hline Canberra & $2950^{b}$ & 16 \\
\hline Brisbane & $17000^{c}$ & 13 \\
\hline Darwin & $1270^{d}$ & -7 \\
\hline \multicolumn{3}{|c|}{$\begin{array}{l}\text { Per capita expenditure has not been calculated as the scope of expen- } \\
\text { diture varies by the nature of the geographic areas covered (e.g. city } \\
\text { council, greater metropolitan area, or statewide). }{ }^{*} \text { Expenditure by state } \\
\text { authority responsible for roads/traffic. }{ }^{* *} \text { Expenditure is across the state. } \\
\text { Source: a Roads and Traffic Authority. RTA Annual Report 2007: p. } 60 \text {. } \\
\text { (Cited } 24 \text { July 2008.) Available from: http://www.rta.nsw.gov.au/ } \\
\text { publicationsstatisticsforms/downloads/2007_rta_annualreport_ } \\
\text { mainbody.pdf bCycling Promotion Fund. State and Territory Spending } \\
\text { on Cycling. Cycling Promotion Fund, Melbourne (2007). 'Brisbane City } \\
\text { Council. Council Budget - Moving Brisbane. (Cited } 11 \text { December } \\
\text { 2008.) Available from:http://www.brisbane.qld.gov.au/bccwr/lib513/ } \\
\text { budget0809_moving_brisbane.pdf }{ }^{d} \text { City of Darwin. 2008/2009 City of } \\
\text { Darwin Annual Plan and Budget. (Cited } 11 \text { December 2008.) Available } \\
\text { from: http://www.darcity.nt.gov.au/documents/2008-09AdoptedCity } \\
\text { ofDarwinAnnualPlanandBudget_000.pdf }\end{array}$} \\
\hline
\end{tabular}

that encourage cycling will readily lead to more Australians cycling.

\section{Recommendations to increase cycling}

The barriers to more Australians cycling are relatively well known. ${ }^{30}$ A report commissioned by the Australian Department of Health and Ageing seeking to raise population levels of physical activity identified the barriers and recommended strategies that a whole-of-government approach could use to increase levels of cycling. ${ }^{22}$ These recommendations are largely dependent upon each other and would need to be implemented in an integrated, co-ordinated way:

- Improved bicycle infrastructure: to provide safe, attractive and enjoyable on and off road bicycle routes as well as high quality end-of-trip facilities.

- Funding: to better reflect the role and value of cycling in a range of areas, including transport, health and sustainability, with support from all levels of government.

- Mass marketing campaigns: to promote the multiple health, environmental, transport, economic and social inclusion benefits of cycling, and address perceived barriers such as safety, required fitness level and roaduser behaviour. These campaigns can be supported through the extensive network of cycling organisations around Australia, and should be combined with infrastructure improvements.

- Behaviour change programs such as TravelSmart, Ride to Work and Ride to School programs: to help more Australian children and adults make the daily commute by bicycle.

- Bicycle events: to encourage infrequent and novice riders to cycle in a supportive social environment.

- Bicycle education programs: to increase confidence and skill levels in both the child and adult population.

- Urban design: to create a physical environment more conducive to cycling, such as higher density, mixed use development and shorter trip distances.

Cycling is a carbon-neutral, petrol-free form of transport, simultaneously helping Australians fight climate change, reduce fuel costs and increase physical activity and improve health. As Australian society comes to terms with global warming and the need to change personal behaviour to slow the rate of climate change, active travel needs to be a central platform in this program. Political will is necessary to create an environment that facilitates walking and cycling, as well as public transport options, for all.

\section{References}

1. NSW Department of Environment and Climate Change. What are greenhouse emissions in NSW? Sydney: NSW Department of Environment and Climate Change; 2008. Available from: http://www.environment.nsw.gov.au/climatechange/ emissionsoverview.htm (Cited 18 October 2008.)

2. Department of Climate Change. State and Territory Greenhouse Gas Inventories 2006. Canberra: Australian Government; 2008. 
Available from: http://www.greenhouse.gov.au/inventory/ stateinv/pubs/states2006.pdf (Cited 27 June 2008.)

3. Parker AA. The end of suburbia: what will happen when all the cheap oil is gone and what are the health implications? Health Promot J Austr 2005; 16(1): 61-8.

4. Rissel C. What price petrol? Health Promot J Austr 2006; 17(1): $3-4$

5. Deffeyes KS. Hubbert's Peak: the impending world oil shortages. Princeton, New Jersey: Princeton University Press; 2003.

6. McCarthy M. Transport and health. In: Marmot M, Wilkinson RG, editors. Social Determinants of Health. Oxford: Oxford University Press; 1999. pp. 132-54.

7. Gordon-Larsen P, Nelson MC, Page P, Popkin BM. Inequality in the built environment underlies key health disparities in physical activity and obesity. Pediatrics 2006; 117(2): 417-24 doi:10.1542/peds.2005-0058

8. Premier's Council for Active Living. What is the Premier's Council for Active Living? Sydney: Premier's Council for Active Living; 2008. Available from: http://www.pcal. nsw.gov.au/ (Cited 22 July 2008.)

9. Gebel K, King L, Bauman A, Vita P, Gill T, Rigby A et al. Creating Healthy Environments - A review on the links between the physical environment, physical activity and health. Sydney: NSW Health Department and NSW Centre for Overweight and Obesity; 2005. Available from: http://www.coo.health.usyd. edu.au/publications/creatin.php (Cited 29 July 2008.)

10. NSW Department of Infrastructure, Planning and Natural Resources and the Roads and Traffic Authority. Planning Guidelines for Walking and Cycling NSW Department of Infrastructure, Planning and Natural Resources. Sydney: Roads and Traffic Authority; 2004.

11. National Heart Foundation of Australia (Victorian Division). Healthy by design: a planner's guide to environments for active living. Melbourne: National Heart Foundation of Australia (Victorian Division); 2004. Available from: http://www. heartfoundation.org.au/SiteCollectionDocuments/ Healthy\%20by\%20Design.pdf (Cited 29 July 2008.)

12. Wen LM, Orr N, Bindon J, Rissel C. Promoting active transport in a workplace setting: evaluation of a pilot study in Australia. Health Promot Int 2005; 20(2): 123-33. doi:10.1093/heapro/dah602

13. Bresciani E, Wen LM, Rissel C, Alley J, Jochelson T. Promoting active transport: where to start? Environ Health 2002; 2(1): 55-60

14. Health Promotion Service, Sydney South West Area Health Service. Cycling Connecting Communities. Sydney: Sydney South West Area Health Service; 2008. Available from: http://cyclingconnectingcommunities.wordpress.com/ (Cited 23 July 2008.)

15. Telfer B, Rissel C, Bindon J, Bosch T. Encouraging cycling through a pilot cycling proficiency training program among adults in central Sydney. J Sci Med Sport 2006; 9(1-2): 151-6. doi:10.1016/j.jsams.2005.06.001

16. Rissel C, Telfer B. Managing risk in a workplace bicycle pool. J Australas Coll Road Safety 2005; 16(1): 18-24.
17. Fry D, Wen LM, Merom D, Dirkis H, Rissel C, Balafas A. Final Report of the Central Sydney Walk to School Research Program 2004-2007. Camperdown: Health Promotion Service, Sydney South West Area Health Service; 2008.

18. Fry D. NSW TravelSmart Schools Program 2006-2007 Summary Report. Sydney: NSW Ministry of Transport, SSWAHS and Australian Greenhouse Office; 2008.

19. Wen LM, Fry D, Rissel C, Dirkis H, Balafas A, Merom D. Factors associated with children being driven to school: implications for walk to school programs. Health Educ Res 2008; 23(2): 325-34. doi:10.1093/her/cym043

20. Boarnet MG, Anderson C, Day K, McMillan T, Alfonzo M. Evaluation of the California Safe Routes to School legislation: Urban form changes and children's active transportation to school. Am J Prev Med 2005; 28(2): 134-40. doi:10.1016/ j.amepre.2004.10.026

21. Australian Sports Commission. Participation in Exercise Recreation and Sport - Annual Report 2006. Canberra: Australian Sports Commission; 2006.

22. Bauman A, Rissel C, Garrard J, Ker I, Speidel R, Fishman E. Cycling - Getting Australia Moving: Barriers, facilitators and interventions to get more Australians physically active through cycling. Melbourne: Cycling Promotion Fund; 2008.

23. Ministry of Transport and Roads and Traffic Authority. Cycling in Sydney - Bicycle ownership and use. Sydney: Ministry of Transport and Roads and Traffic Authority; 2008.

24. Cycling Promotion Fund. Bicycle Outsells cars in Australia sales top 1.4 million. Melbourne: Cycling Promotion Fund; 2008. Available from: http://www.cyclingpromotion.com.au/ latest-news/page_3.html (Cited 24 July 2008.)

25. Bicycle Victoria. Transport and Liveability Statement provides \$72 million for riders. Melbourne: Bicycle Victoria; 2007. Available from: http://www.bv.com.au/change-the-world/ 12064 (Cited 24 July 2008.)

26. Roads and Traffic Authority. RTA Annual Report 2007. Sydney: Roads and Traffic Authority; 2007. p. 60. Available from: http:/www.rta.nsw.gov.au/publicationsstatisticsforms/ downloads/2007_rta_annualreport_mainbody.pdf (Cited 24 July 2008.)

27. Cycling Promotion Fund. London increases its cycling budget. Melbourne: Cycling Promotion Fund; 2008. Available from: http://www.cyclingpromotion.com.au/latest-news/latest/ london-increases-its-cycling-budget.html (Cited 24 July 2008.)

28. Campbell R. Bicycle Friendly City [online]. In: 1989 National Transport Conference: Transport for the Users; Preprint of Papers. Barton, ACT: Institution of Engineers, Australia; 1989. pp. 214-8. National conference publication (Institution of Engineers, Australia); no. 89/7. Available from: http://search. informit.com.au/documentSummary; $\mathrm{dn}=820558195016115$; res=IELENG (Cited 15 October 2008.)

29. Rissel C, Garrard J. Cycling for active transport and recreation in Australia: status review and future directions. World Transp Policy Pract 2006; 13(1): 49-63.

30. Daley M, Rissel C, Lloyd B. All dressed up and no-where to go? A qualitative research study of the barriers and enablers to cycling in inner Sydney. Road Transport Res 2007; 16(4): 42-52. 


\section{Functional foods and urban agriculture: two responses to climate change-related food insecurity}

\author{
Jane M. Dixon ${ }^{\mathrm{A}, \mathrm{C}}$, Kelly J. Donati ${ }^{\mathrm{B}}$, \\ Lucy L. Pike $e^{\mathrm{B}}$ and Libby Hattersley \\ ${ }^{\mathrm{A} N a t i o n a l ~ C e n t r e ~ f o r ~ E p i d e m i o l o g y ~ a n d ~ P o p u l a t i o n ~ H e a l t h, ~}$ \\ Australian National University \\ ${ }^{\mathrm{B}}$ Melbourne School of Land and Environment, \\ University of Melbourne \\ ${ }^{\mathrm{C} C o r r e s p o n d i n g ~ a u t h o r . E m a i l: ~ j a n e . d i x o n @ a n u . e d u . a u ~}$
}

\begin{abstract}
Affluent diets have negative effects on the health of the population and the environment. Moreover, the ability of industrialised agricultural ecosystems to continue to supply these diets is threatened by the anticipated consequences of climate change. By challenging the ongoing supply of the diets of affluent countries, climate change provides a population and environmental health opportunity. This paper contrasts two strategies for dealing with climate change-related food insecurity. Functional foods are being positioned as one response because they are considered a hyper-efficient mechanism for supplying essential micronutrients. An alternative response is civic and urban agriculture. Rather than emphasising increased economic or nutritional efficiencies, civic agriculture presents a holistic approach to food security that is more directly connected to the economic, environmental and social factors that affect diet and health.
\end{abstract}

There is growing awareness that diets in affluent countries, rich in meat protein, dairy and preprepared foods, have a negative impact on biophysical environments as well as on public health. ${ }^{1-4}$ Consensus is also emerging that healthier diets are more environmentally sustainable. ${ }^{4-6}$ By challenging the ongoing supply of affluent country diets, climate change provides a population and environmental health opportunity. However, it also poses a significant risk to food-insecure populations. Already, data show that undernutrition in less affluent countries is rising; and due to higher food prices, poorer subpopulations in the developed world are missing out on a range of protective foods, like fruit and vegetables, and in the developing world, staples like rice, maize and wheat. ${ }^{7-9}$

This paper focuses on the opportunities for food system transformations posed by climate change. It begins by sketching the symbiotic relationship between climate change and sustainable food yields, before contrasting two strategies for dealing with anticipated food shortages and the associated growth in diet-related diseases: the promotion of the functional food sector and civic and urban agriculture. While examples of civic agriculture such as farmers' markets and food co-operatives are relatively recent in Western countries, urban agriculture has a long tradition as a localised response to food shortages, the degradation of urban communities and urban poverty in cities in both developed and developing countries. With over half of the global population living in cities, urban agriculture may have significant implications for rethinking conventional approaches to agrifood systems.

\section{Industrial food systems and climate change}

Food is a major user of energy and thus contributor to greenhouse gas emissions, with 15 to $20 \%$ of energy used in developed countries attributed to their food sectors. ${ }^{5}$ In Australia, emissions from agriculture accounted for $16 \%$ of net emissions in $2004 .{ }^{10}$ This proportion increases to $23 \%$ when producer emissions from energy, transport and waste are included. ${ }^{3}$ The entire food chain is implicated, with household food preparation, organic waste disposal and car shopping trips adding a further $10 \%$ to emissions. ${ }^{3}$

In Europe, and we assume Australia, the most energy intensive food commodities are the most health damaging: animal-based foods, fats and oils, and sweets, snacks and drinks. ${ }^{5,11}$ While there is popular debate about the distance that foods travel, or food miles, it is the mode of transport that is important. The $1 \%$ of foods known to be airfreighted in the United Kingdom (UK) accounts for 11\% of food transport's overall contribution to carbon dioxide. ${ }^{12}$ Global free trade arrangements will deepen the 


\section{Box 1. Life cycle assessment in the agrifood sector}

Life cycle assessment is a tool for the systematic evaluation of the environmental aspects of specific products over their life cycle (from cradle to grave). ${ }^{13}$ The technique emerged from the industrial and commercial sectors and has been internationally standardised since $1997 .{ }^{14}$ Unlike other approaches to environmental impact assessment, it includes all supporting processes within a system and allows for multiple environmental indicators to be assessed concurrently.

Within the agrifood sector, the technique is attracting growing commercial interest as a tool for communicating broader environmental information to increasinglyinterested stakeholders. It is of particular relevance to environmental health officers and urban planners, and could facilitate food consumers to become climate watchers as they monitor the environmental consequences of their household food behaviours. ${ }^{5}$

extent of air-freighted foods. It is now generally recognised that the food miles metric is a poor proxy for environmental damage, and that lifecycle assessments from paddock to plate are important. ${ }^{3}$

As a result of climate change, food yields are declining albeit unevenly across the globe. . $9,15,16$ Reduced cereal and rice yields are the most troubling in terms of food insecurity in poorer countries. Declines result from either too little or too much rainfall, soil loss due to winds, higher temperatures, storm and hail damage to crops, and the spread of pests and plant and animal diseases. ${ }^{17}$ Australia's major food production region based on the Murray-Darling river system is collapsing due to inadequate water flows and increased temperatures. ${ }^{17}$

Climate change is also compromising food yields indirectly, through:

1. redirecting agricultural efforts away from human food to biofuel production as a strategy for reducing greenhouse gas emissions related to fossil fueldependant industries

2. reduced fishing permits near distressed marine ecosystems, for example, the Great Barrier Reef

3. the growth of aquaculture as a response to exhausted capture of wild fisheries, further disturbing these more traditional fish sources. ${ }^{17,18}$

\section{The functional food response}

For more than a century, governments have periodically called on food manufacturers to fortify foods and drinks as a population-wide strategy for eliminating micronutrient deficiencies: for example, iodised salt and thiamineenriched beer. ${ }^{19,20}$ Since the 1980s, nutrient enrichment (energy drinks, vitamin-fortified cereals) and nutrition engineering (reduced-fat milk) have also taken place independently of government. ${ }^{21}$ These commodities have been called corporate marketing devices for value-adding health to foods, and they may be redundant in countries where food supplies are replete with nutrients. ${ }^{22,23}$

To date, most functional food activity has occurred in the developed world where people can afford to pay more for the value-added items. Involving the largest agrifood and pharmaceutical corporations, it is a hugely profitable sector estimated to be worth US\$30-50 billion in 2004, with large annual growth forecasts. ${ }^{20}$

In part, because of success with golden rice (rice that is genetically engineered to deliver vitamin A), and the green revolution, an argument is gaining momentum that foods genetically modified to produce essential micronutrients are an important technological response to improving the nutrient values of the reduced food supply. ${ }^{24}$ What is often overlooked is that the green revolution contributed to marked rural inequalities and despoiled agricultural environments. ${ }^{25,26}$

There is good reason to fortify food supplies where micronutrient deficiencies exist, especially in the developing world where food scarcity is an issue, but the functional food sector has major shortcomings as a response to climate changeinduced food insecurity. ${ }^{27}$ First, it does little to challenge industrial agriculture and its externalities, including climate change. Second, it does not guarantee a balanced and diverse diet, which bodies like the World Health Organization deem important for health. ${ }^{28}$ Third, it does not address another determinant of good nutrition: household incomes. Even in wealthy countries, climate change is driving farmers off their land into cities in search of employment. ${ }^{15}$ Farmer and peasant reliance on cash incomes for food previously acquired through various self-sufficiency strategies can lead to inferior diets. ${ }^{29}$ Finally, by limiting participation in the food system to the act of purchasing and consuming nutrients, it does not engage consumers with their food supply.

\section{The civic and urban agriculture response}

An alternative response to a corporate approach (that is, led by large-scale, profit-driven corporations) is civic and urban agriculture. Civic agriculture emerged out of the environmental and food counterculture movements of the 1960s and 1970s. It shifts the focus away from simply increasing economic or nutritional efficiencies in food production, instead adopting a broader perspective, which uses localised food production as a way of developing and strengthening communities. ${ }^{30}$

Urban agriculture is an important aspect of civic agriculture in cities in both developing and developed countries. For example, when Cuba lost access to cheap fuel and petrochemical-based agricultural chemicals in the mid1990s, it worked to secure a sustainable and healthy food supply through organic food production (for both export and domestic consumption and urban agriculture). ${ }^{31}$ For cities and urban areas in South America, Africa and the 
Pacific Islands, growing food provides a source of fresh, affordable and culturally-appropriate food, though urban agriculture has received relatively little institutional support from planners and policy makers. ${ }^{32-34}$

Urban agriculture as a strategy for addressing food security issues has not been restricted to the developing world. In Europe and North America, it has historically inhabited a variety of spaces, taking the form of allotments and community gardens, backyards, urban and peri-urban farms, vacant lots, schools and public land. It has been incorporated within radical and conservative political agendas as a response to a variety of economic and social crises, from citizen protest and world wars to mass unemployment and urban degeneration. During the 18th and 19th centuries, low-rent allotments for establishing food gardens were made available in the UK through social reform programs to new landless peasants in order to subsidise the incomes and diets of the urban poor. ${ }^{35,36}$

The literature about urban agriculture and community gardening points to numerous potential social, ecological and health benefits. The therapeutic value of community gardening as a physical activity has been recognised for creating opportunities for ecological engagement and 'emotional, physical and spiritual renewal' and for contributing to the health and wellbeing of the elderly. ${ }^{37}$ Food gardening as a leisure activity is associated with building stronger relationships and social capital at a local level. ${ }^{38}$ A study of allotment gardens in Barcelona, Spain, found that, beyond providing a source of food, allotment gardening also makes use of the skills and knowledge brought by retirees from rural areas, such that the community garden was 'a space of physical and psychological well-being and communion with a former rural life that they had to abandon when migrating towards the industrial centres' ${ }^{39}$ Gardening programs for children have also emerged in schools with the aim of teaching children about the origins of what they eat, the ecological processes of food production and the importance of the table as a social space. ${ }^{40}$

In the San Francisco area, urban food gardens were found to be strongly aligned with the objectives of Local Agenda 21 and played an important role in the greening of lowincome neighbourhoods and in revitalising the 'ecological and social health' of degraded urban communities. ${ }^{41}$ Community garden participation has also been associated with increased consumption of fresh fruit and vegetables among gardeners, pointing to its potential as an approach for improving diet-related health that may also contribute to wellbeing in less tangible ways. ${ }^{42}$ Urban agriculture has more recently been used as a strategy for nutritional and environmental education and community development. It is associated with the community food security movement to support 'cultural identity, citizenship and democratic practice' through localised food production and consumption. ${ }^{43}$ Civic participation and community organising are important dimensions of many urban agriculture projects and suggest further potential for developing healthier and more vibrant communities.

With the political backing of government, the Victory Gardens program in the United States was hugely productive with approximately $40 \%$ of fresh vegetables consumed from an estimated 20 million gardens during World War II, enabling mainstream food resources to be shipped to troops overseas. ${ }^{44}$ This suggests that, when adequately supported by government, urban agriculture has enormous potential as a localised food source. However, while it has potentially important implications for how city planners might incorporate food production into the city, urban agriculture is a relatively marginal practice in relation to conventional approaches to urban development in the West. ${ }^{45}$

Desilvey suggests that the diversified uses of community gardens and allotments as 'urban green spaces, poor relief schemes, wartime provisioning centres and landscapes of leisure' has meant that they tend to fall between the cracks of traditional urban planning in Western cities. ${ }^{36}$ In fact, community gardens and other urban agriculture sites have long been politically contested spaces between gardening residents, municipal government, private developers and community and grassroots organisations, particularly as they often have competing interests and differing degrees of power and agency in how urban land is allocated and managed. ${ }^{39,46}$

The contested nature of urban agriculture sites and a lack of appropriate institutional support present significant challenges to urban agriculture as a response to food insecurity and climate change. With land values in Australian cities rising significantly over the last decade, urban agriculture organisations often compete with developers for access to land. Nonetheless, the importance of community gardens to residents of some of Melbourne's high-rise public housing flats and community gardening volunteers is potentially profound. Cultivating a garden plot provides not only an affordable source of fresh, healthy food and opportunities for exercise, but also supplies residents with foods that are connected to their cultural heritage and that are important to feasts and celebrations. As Bhatti and Church suggest, public and private food gardens produce spaces in which people can 'develop complex, sensual and personalised readings of nature' and places to 'engage, confront and understand the changing natural world' ${ }^{47}$

Several Melbourne-based urban agriculture projects, such as an urban farm and mushroom growing project at Ceres and the former Garden of Eden permaculture food garden in Albert Park, have developed as social enterprise projects for learning and training as well as for reducing social exclusion and increasing ecological literacy. Many community gardening organisers are seeking to develop local responses to broader global issues such as climate change, 
health problems, increasing urbanisation and the inequities of the industrial food system. Sites of urban agriculture are often hotbeds of environmental, cultural and social activism and spaces of civic engagement that provide a precious economic, social and cultural resource for the community. This suggests that urban agriculture warrants further examination for its potential not only in developing alternative food systems that are more socially and environmentally sustainable but also in creating more engaged food citizens and building more ecologically and socially healthier communities. ${ }^{48}$

Urban agriculture makes food systems more visible and brings agriculture into urban life in new and enriching ways. As Delind argues, it is not enough to grow more food locally, calling for projects which 'reintegrate agriculture, its rhythms, sensibilities, and trappings back into our daily lives. Not only do we need to make such activity visible and accessible, we also need to make it convivial and sensual' ${ }^{49}$ As cities like Vancouver and Toronto, Canada, and municipalities in Australia begin developing urban food policies, urban agriculture projects from community gardens to social enterprise programs are developing viable and engaging alternatives to conventional techno-industrial agrifood responses to climate change and food insecurity, such as functional foods and genetically modified agriculture. These approaches tend to alienate rather than connect consumers to the food system and diminish rather than strengthen social and ecological connections through food. Not enough is understood, as Donald and Blay-Palmer point out, of how the urban foodcreative economy might foster 'political innovations' and offer 'potential for a more socially inclusive urban development model' and a more ecological approach to dietrelated public health issues..$^{50}$

\section{Conclusion}

Plant-based diets, organic food systems and food systems based on small-scale, local production and distribution networks are becoming increasingly recognised as healthier and more environmentally sustainable approaches than the present global, industrial (energy-intensive) and animal-based system. Civic agriculture presents a holistic approach to food insecurity that is more attentive and responsive to the local economic, environmental and social factors that affect diet and health.

\section{References}

1. Elinder L. Obesity, hunger and agriculture: the damaging role of subsidies. BMJ 2005; 331: 1333-6. doi:10.1136/ bmj.331.7528.1333

2. McMichael A. Integrating nutrition with ecology: balancing the health of humans and biosphere. Public Health Nutr 2005; 8(6A): 706-15.

3. Larsen K, Ryan C, Abraham A. Sustainable and secure food systems for Victoria: What do we know? What do we need to know? Melbourne: Victorian Eco-Innovation Lab (VEIL),
Australian Centre for Science, Innovation and Society, University of Melbourne; 2008. VEIL Research Report: No. 1.

4. Steinfeld H, Gerber P, Wassenaar T, Castel V, Rosales M, de Haan C. Livestock's long shadow: environmental issues and options. Rome, Italy: Food and Agriculture Organization of the United Nations (FAO), Livestock, Environment and Development Initiative; 2006.

5. Carlsson-Kanyama A, Ekstrom M, Shanahan H. Food and life cycle energy inputs: consequences of diet and ways to increase efficiency. Ecol Econ 2003; 44: 293-307. doi:10.1016/S09218009(02)00261-6

6. Franco M, Orduñez P, Caballero B, Tapia Granados JA, Lazo M, Bernal JL et al. Impact of energy intake, physical activity, and population-wide weight loss on cardiovascular disease and diabetes mortality in Cuba, 1980-2005. Am J Epidemiol 2007; 166(12): 1374-80. doi:10.1093/aje/kwm226

7. Schmidhuber J, Tubiello F. Global food security under climate change. Proc Natl Acad Sci USA 2007; 104(50): 19703-8. doi:10.1073/pnas.0701976104

8. Sturm R, Datar A. Body mass index in elementary school children, metropolitan area food prices and food outlet density. Public Health 2005; 119(12): 1059-68. doi:10.1016/ j.puhe.2005.05.007

9. Cohen M, Cristina Tirado C, Noora-Lisa Aberman N-L, Thompson B. Impact of climate change and bioenergy on nutrition. Washington, DC: The International Food Policy Research Institute and Food and Agriculture Organization of the United Nations; 2008.

10. Secretary-General, Organisation for Economic Co-operation and Development (OECD). Promoting sustainable consumption: good practice in OECD countries. Geneva: OECD; 2008. Available from: http://www.oecd.org/dataoecd/1/59/ 40317373.pdf (Cited 01 December 2008.)

11. Oresund Food Network and Oresund Environment Academy. Climate change and the food industry: climate labelling for food products; potential limitations. Copenhagen: Oresund Food Network and Oresund Environment Academy; 2008. Available from: http://www.oresundfood.org/files/1a5d40e38e_ oefn-oeea_rapport_v04.pdf (Cited 01 December 2008.)

12. MacMillan T, Alston L, Segal R, Steedman P. Flying food: responsible retail in the face of uncertainty. Brighton: Food Ethics Council; 2008. Available from: http://www. foodethicscouncil.org/files/flyingfood.pdf (Cited 01 December 2008.)

13. United Nations Environment Programme (UNEP)/Society of Environmental Toxicology and Chemistry (SETAC). Life cycle initiative. Nairobi, Kenya: UNEP/SETAC; 2007. Available from: http://lcinitiative.unep.fr/ (Cited 01 December 2008.)

14. International Organization for Standardization (ISO). TC 207/SC 5 - Life cycle assessment. Geneva: ISO; 2008. Available from: http://www.iso.org/iso/iso_catalogue/ catalogue_tc/catalogue_tc_browse.htm?commid $=54854 \&$ published $=$ on (Cited 01 December 2008.)

15. Horton G, McMichael A. Climate Change Health Check 2020. Canberra: Doctors for the Environment, Australia; 2008. Available from: http://www.dea.org.au/UserFiles/File/pdf_ documents/Climate_Change_Health_Check_2020.pdf (Cited 01 December 2008.)

16. Howden MS, Soussana J-F, Tubiello, Chhetri N, Dunlop M, Meinke H. Adapting agriculture to climate change. Proc Natl 
Acad Sci USA 2007; 104(50): 19691-6. doi:10.1073/ pnas.0701890104

17. Prime Minister's Science Engineering and Innovation Council Independent Working Group. Climate change in Australia: regional impacts and adaptation, managing the risk for Australia. Canberra: Prime Minister's Science, Engineering and Innovation Council; 2007. Available from: http://www.dest. gov.au/NR/rdonlyres/CE5D024E-8F58-499F-9EEBD2D638E7A345/17397/ClimateChangeinAustraliareport.pdf (Cited 01 December 2008.)

18. Brander K. Global fish production and climate change. Proc Natl Acad Sci USA 2007; 104(50): 19 709-14. doi:10.1073/ pnas.0702059104

19. Dixon J, Hinde S, Banwell C. Obesity, convenience and 'phood'. Br Food J 2006; 108(8): 634-5. doi:10.1108/ 00070700610682328

20. Lawrence M, Germov J. Functional foods and public health nutrition policy. In: Germov J, Williams L, editors. A sociology of food and nutrition. South Melbourne: Oxford University Press; 2008. pp. 147-75.

21. Heasman M, Mellentin J. The functional food revolution: healthy people, healthy profits. London: Earthscan; 2001.

22. Scrinis G. Functional foods, functionally marketed foods? A critique of, and alternatives to, three categories of 'functional foods'. Public Health Nutr 2008; 11(5): 541-5. doi:10.1017/ S1368980008001869

23. Nestle M. Food Politics. Berkeley: University of California Press; 2002.

24. Dawe D, Robertson R, Unnevehr L. Golden rice: what role could it play in alleviation of vitamin A deficiency? Food Policy 2002; 27: 541-60. doi:10.1016/S0306-9192(02)00065-9

25. McMichael P. The global restructuring of agro-food systems. Ithaca: Cornell University Press; 1994.

26. Moore J. Environmental crises and the metabolic rift in worldhistorical perspective. Organ Environ 2000; 13(2): 123-57. doi:10.1177/1086026600132001

27. The World Bank. Repositioning nutrition as central to development: A strategy for large-scale action. Washington DC: The International Bank for Reconstruction and Development and The World Bank; 2006.

28. World Health Organization. Global Strategy on Diet, Physical Activity and Health. Geneva: World Health Organization; 2004. Available from: http://www.who.int/dietphysicalactivity/ strategy/eb11344/en/index.html (Cited 01 December 2008.)

29. Kjellstrom T. Our cities, our health, our future. Kobe, Japan: WHO Centre for Health Development; 2008. Available from: http://www.who.int/social_determinants/resources/ knus_report_16jul07.pdf (Cited 01 December 2008.)

30. Lyson T. Civic agriculture: Reconnecting farm, food and community. Medford, Massachusetts: Tufts University Press; 2004.

31. Altieri M, Companioni N, Canizares K, Murphy C, Rosset P, Nicholls C. The greening of the 'barrios': Urban agriculture for food security in Cuba. Agric Human Values 1999; 16: 131-40. doi:10.1023/A:1007545304561

32. Thaman R. Urban food gardening in the Pacific Islands: A basis for food security in rapidly urbanising small-island states. Habitat Int 1995; 19(2): 209-24. doi:10.1016/0197-3975 (94)00067-C
33. WinklerPrins A, de Souza P. Surviving the city: urban home gardens and the economy of affection in the Brazilian Amazon. Journal of Latin American Geography 2005; 4(1): 107-26. doi:10.1353/lag.2005.0033

34. Asomani-Boateng R. Urban cultivation in Accra: an examination of the nature, practices, problems, potentials and urban planning implications. Habitat Int 2002; 26: 591-607. doi:10.1016/S0197-3975(02)00027-9

35. Moselle B. Allotments, enclosure, and proletarianization in early nineteenth-century Southern England. Econ Hist Rev 1995; 48(3): 482-500.

36. Desilvey C. Cultivated histories in a Scottish allotment garden. Cult Geogr 2003; 10: 442-68. doi:10.1191/ 1474474003 eu284oa

37. Milligan C, Gatrell A, Bingley A. Cultivating health: therapeutic landscapes and older people in northern England. Soc Sci Med 2004; 58: 1781-93. doi:10.1016/S0277-9536(03)00397-6

38. Glover T, Parry D. Building relationships, accessing resources: mobilizing social capital in community garden contexts. J Leisure Res 2005; 37(4): 450-74.

39. Domene E, Saurí D. Urbanization and class-produced natures: vegetable gardens in the Barcelona Metropolitan Region. Geoforum 2007; 38: 287-98. doi:10.1016/j.geoforum. 2006.03.004

40. Pudup MB. It takes a garden: Cultivating citizen-subjects in organized garden projects. Geoforum 2008; 39(3): 1228-40. doi:10.1016/j.geoforum.2007.06.012

41. Ferris J, Norman C, Sempik J. People, land and sustainability: community gardens and the social dimension of sustainable development. Soc Policy Adm 2001; 35(5): 559-68. doi:10.1111/1467-9515.t01-1-00253

42. Alaimo K, Packnett E, Miles R, Kruger D. Fruit and vegetable intake among urban community gardeners. J Nutr Educ Behav 2008; 40(2): 94-101. doi:10.1016/j.jneb.2006.12.003

43. Baker L. Tending cultural landscapes and food citizenship in Toronto's community gardens. Geogr Rev 2004; 94(3): 305-25.

44. Hynes H. A patch of eden: America's inner-city gardeners. White River Junction, VT: Chelsea Green Publishing Company; 1996.

45. Howe J. Planning for urban food: the experience of two UK cities. Plann Pract Res 2002; 17(2): 125-44. doi:10.1080/ 02697450220145904

46. Schmelzkopf K. Urban gardens as contested space. Geogr Rev 1995; 85: 364-81. doi:10.2307/215279

47. Bhatti M, Church A. Cultivating natures: homes and gardens in late modernity. Sociology 2001; 35(2): 365-83.

48. Buttel F. Some observations on agro-food change and the future of agricultural sustainability movements. In: Goodman D, Watts M, editors. Globalising Food. London: Routledge; 1997. pp. 344-65.

49. Delind L. Of bodies, place, and culture: re-situating local food. J Agric Environ Ethics 2006; 19: 121-46. doi:10.1007/ s10806-005-1803-z

50. Donald B, Blay-Palmer A. The urban creative-food economy: producing food for the urban elite or social inclusion opportunity? Environ Plan A 2006; 38: 1901-20. doi:10.1068/a37262 


\section{An extreme bushfire smoke pollution event: health impacts and public health challenges}

\author{
Anthony Kolbe ${ }^{\mathrm{A}}$ and Kim L. Gilchrist ${ }^{\mathrm{A}, \mathrm{B}}$ \\ APopulation Health, Greater Southern Area Health Service \\ ${ }^{\mathrm{B} C o r r e s p o n d i n g}$ author. Email: kim.gilchrist@gsahs.health. \\ nsw.gov.au
}

\begin{abstract}
Aims: To determine the health impacts of smoke and the effectiveness of public health advisories during a severe bushfire smoke event in Albury, NSW. Methods: The NSW Department of Environment and Climate Change provided $\mathrm{PM}_{10}$ data. A computer-assisted telephone survey using random digit dialling was conducted following the smoke event to assess health impacts and the effectiveness of advisories. Results: The smoke event lasted 38 days. The maximum daily $\mathrm{PM}_{10}$ level was $415 \mu \mathrm{g} / \mathrm{m}^{3}$. Public health advisories were based on alerts for air pollution issued by NSW Department of Health. From the survey, a total of 389 interviews were available for analysis. At least one health effect of the smoke was reported by $70 \%$ of respondents and 5\% reported seeking medical treatment. Over $74 \%$ reported seeing, hearing or reading the health advisories. Behaviour change was significantly greater in this group (odds ratio $=2.74 ; 95 \%$ confidence interval 1.50-5.02). Conclusion: High rates of health effects may be experienced by populations exposed to bushfire smoke pollution. Public health advisories can support behaviour change to reduce exposure to bushfire smoke.
\end{abstract}

Smoke pollution from bushfires is associated with respiratory effects and the toxicity of particulate matter sourced from bushfires is similar to that originating from urban sources. ${ }^{1}$ An increase in the frequency of very high and extreme fire danger days in south-eastern Australia is predicted with climate change. ${ }^{2}$ Health impacts due to bushfire smoke pollution may also increase.
In early 2003, smoke from bushfires blanketed north-eastern Victoria and southern New South Wales (NSW). Smoke pollution was present continuously in the city of Albury, NSW for 38 days and in late January and early February extreme levels were experienced. Studies examining the health impact of severe bushfire smoke pollution in a community setting are limited in Australia and studies on presentations at emergency departments during smoke events have produced inconsistent results. ${ }^{3-5}$ Low level particulate pollution arising from vegetation burning in Australia has been associated with asthma symptoms and medication use. ${ }^{6}$

This paper describes a bushfire smoke event, the role of public health during the event and a survey conducted to determine the health impacts of the smoke and the effectiveness of public health advisories, which were published through the mainstream news media.

\section{Materials and methods}

To inform public health advisories, draft health alerts for air pollution from the NSW Department of Health and air quality data $\left(\mathrm{PM}_{10}\right)$ provided by the NSW Department of Environment and Climate Change (DECC) were used. A community survey was conducted shortly after the pollution abated using a computer-assisted telephone interview (CATI) technique and random digit dialling. The event was defined as the 38-day period from when the daily $\mathrm{PM}_{10}$ result for the Albury Local Government Area (LGA) first exceeded $50 \mu \mathrm{g} / \mathrm{m}^{3}$ to when daily results were consistently below this level.

\section{Air quality measurement}

DECC operates an air quality monitoring site in Albury using a tapered element oscillating microbalance (TEOM), which provides a measure of particulate concentration by calculating the change in mass of a filter, detected by the alteration in the oscillation rate of the collection tube. The TEOM was set to provide a measure of particulate matter with an equivalent aerodynamic diameter of $10 \mu \mathrm{m}$ or less $\left(\mathrm{PM}_{10}\right)$. The daily $\mathrm{PM}_{10}$ result was calculated as the arithmetic mean of the 241 -hour averages and was provided by DECC the following day. For calculation of the daily average at least $75 \%$ of the hourly averages must be available.

\section{Survey methodology}

The survey questionnaire was developed in consultation with the NSW Department of Health and interviews were 


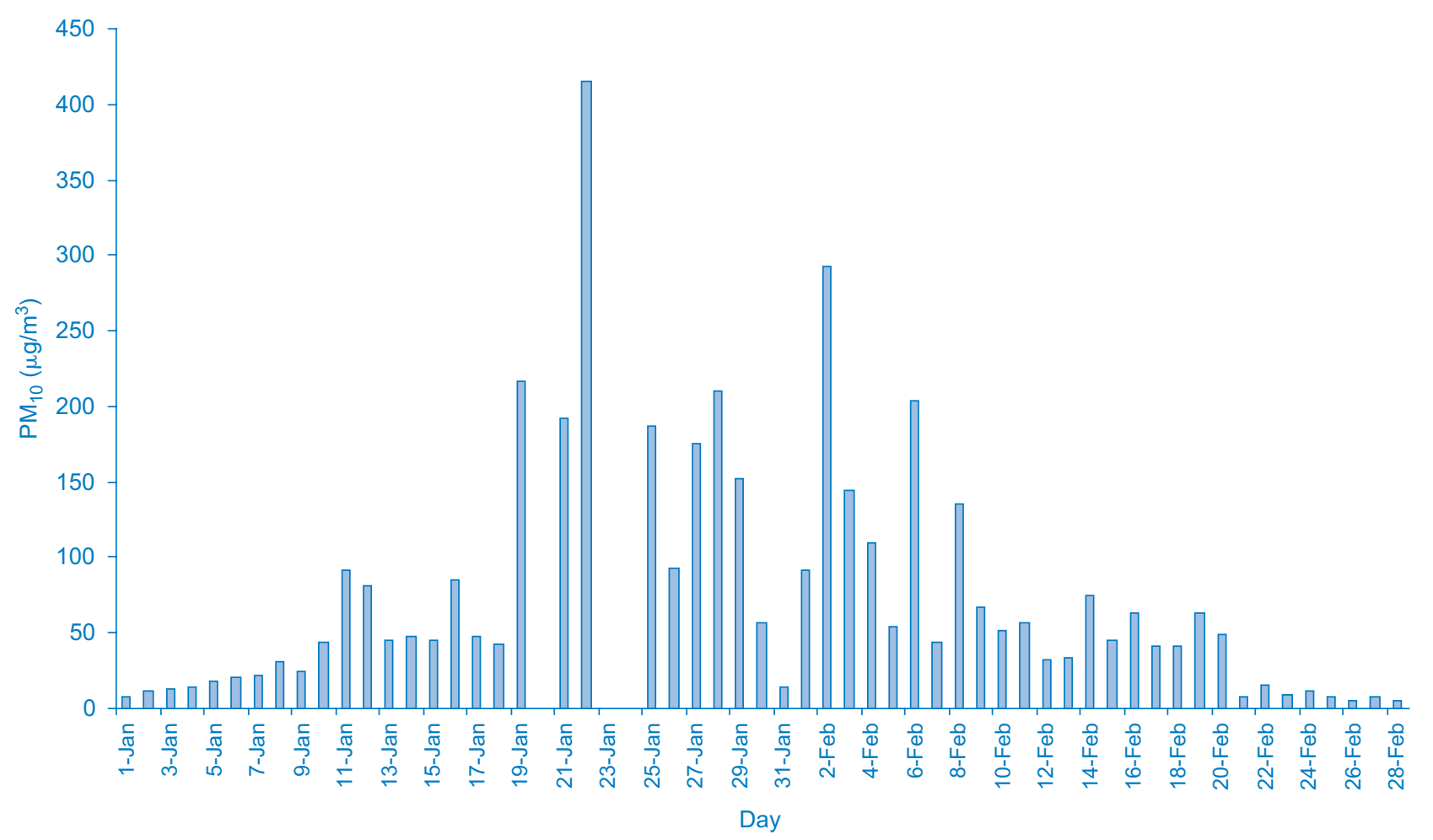

Figure 1. Daily average $\mathrm{PM}_{10}$ results $\left(\mu \mathrm{g} / \mathrm{m}^{3}\right.$ ) for the period 1 January to 28 February 2003, Albury, NSW.

undertaken by the Department's CATI team. A pilot survey of 12 respondents was conducted. The common responses to the open ended questions of the pilot survey were used to identify the categories for responses in the main survey with allowance for other responses. Telephone numbers were selected randomly from a bank of numbers for the Albury LGA. Once the household was contacted the respondent was randomly selected from all household members. Respondents who did not speak English were excluded from the survey. (Census 2001 reported $0.3 \%$ of Albury LGA could not speak English well or not at all. ${ }^{7}$ ) Informed consent was obtained at the start of the interview. Information on pre-existing health conditions, as diagnosed by a medical practitioner, was self-reported. People aged 16 years and above were questioned. Where the selected household respondent was less than 16 years of age, a parent or carer was asked to complete the survey on the child's behalf. The survey was conducted over a 2-week period in late February and early March 2003. The responses were weighted according to the December 2002 Estimated Resident Population for the Albury LGA and data were analysed using SAS Version 9.1. Ethical approval for the study was obtained through the Greater Murray Area Health Service Human Research Ethics Committee.

\section{Results}

Air quality results

NSW Health has adopted an air quality categorisation system developed by DECC for public health advice on air pollution. ${ }^{8}$ The DECC system reports air quality using a derived value called the air quality index (AQI). ${ }^{9}$ The maximum daily $\mathrm{PM}_{10}$ result during the bushfire smoke event was $415 \mu \mathrm{g} / \mathrm{m}^{3}$ (Figure 1), equivalent to an $\mathrm{AQI}$ of 830. The same day, the maximum hourly result of $938 \mu \mathrm{g} / \mathrm{m}^{3}$ was recorded. On 3 days, the average daily $\mathrm{PM}_{10}$ result was not able to be calculated as the monitoring device was rendered inoperable by the high pollution levels. For these 3 days, hourly results were possible for 13,10 and 11 readings respectively. Using these readings, the average daily results for 20, 23 and 24 January 2003 were 263,702 and $140 \mu \mathrm{g} / \mathrm{m}^{3}$ respectively. Based on the AQI categorisation and using the results from the complete daily averages and the three incomplete days, the air quality during the 38-day period, consisted of 15 days considered as 'hazardous', 6 days as 'very poor', 7 days as 'poor' and 9 as 'fair'.

\section{Public health advisories}

Advisories were published through the mainstream news media and, initially, targeted people with existing cardiovascular or respiratory disease, elderly people and children. As the pollution worsened and reached levels considered very poor or hazardous, the advisories were directed at the whole community. Early advisories stated that at-risk individuals should avoid strenuous outdoor exercise, take their medication as prescribed, follow established action plans and seek medical attention if they experienced asthma, chest pain or shortness of breath. As the pollution worsened, the general public was advised to 
reduce the level of outdoor activity and, as hazardous levels were recorded, to stay indoors as much as possible. A fact sheet was prepared and sent to all general practitioners and hospitals in the affected area. Similar information was provided to all aged-care facilities, child-care facilities and, through the NSW Department of Education and Training, to schools. The local public health unit received enquiries during this period from schools, businesses, organisations and individuals seeking advice regarding outdoor events.

When $\mathrm{PM}_{10}$ results far exceeded the highest level of the health alerts, further action was considered. The use of clean air respite facilities was considered and a trial clean

Table 1. Symptoms experienced during a smoke event by reported pre-existing health condition in Albury, NSW, January-February 2003

\begin{tabular}{|c|c|c|c|c|}
\hline \multirow[t]{2}{*}{ Symptom } & \multicolumn{3}{|c|}{ Health condition ${ }^{a}(\%)$} & \multirow{2}{*}{$\begin{array}{c}\text { All (\%) } \\
n=389\end{array}$} \\
\hline & CVD & Respiratory & Asthma & \\
\hline Eye irritation & 60.9 & 63.7 & 66.1 & 52.8 \\
\hline Coughing & 47.3 & 47.6 & 49.4 & 32.4 \\
\hline Throat irritation & 36.6 & 34.9 & 34.9 & 29.0 \\
\hline $\begin{array}{l}\text { Shortness of } \\
\text { breath }\end{array}$ & 43.2 & 42.5 & 44.2 & 24.3 \\
\hline Headache & 21.9 & 23.6 & 22.2 & 19.4 \\
\hline Wheezing & 20.4 & 24.0 & 25.6 & 11.6 \\
\hline Asthma & 19.1 & 33.3 & 39.1 & 10.7 \\
\hline Anxiety & 19.2 & 16.1 & 16.3 & 9.0 \\
\hline Depression & 13.6 & 6.5 & 6.1 & 5.0 \\
\hline Other & 6.2 & 3.4 & 2.9 & 4.5 \\
\hline Bronchitis & 1.9 & 5.1 & 5.7 & 2.1 \\
\hline Angina & 1.6 & 0.0 & 0.0 & 0.2 \\
\hline Any symptoms & 82.6 & 84.9 & 88.1 & 70.4 \\
\hline \multicolumn{5}{|c|}{$\begin{array}{l}\text { aPercentages calculated on } 77 \text { people who reported heart condi- } \\
\text { tions, } 105 \text { respiratory conditions (including asthma) and } 82 \text { asthma. } \\
\text { Some people had more than one condition and are therefore } \\
\text { included in more than one category. CVD, cardiovascular disease. }\end{array}$} \\
\hline
\end{tabular}

air room using air cleaning devices was established at Albury Base Hospital. The availability and cost of air cleaning devices was investigated.

Local supplies of disposable respiratory masks were identified and monitored. The use of masks was included in the public health advisories although, due to time constraints, information was not provided on the methods for fit testing. Consideration was given to the need for selected or mass evacuation and discussions were held with the local emergency management committee; however, public health surveillance did not support the need for mass evacuation.

\section{Survey results}

A total of 1463 calls were made to achieve 415 interviews. There were 97 refusals including both household and respondent refusals, giving a response rate of $81.1 \%$. Twenty-six responses were excluded from the analysis because the selected respondent was not in Albury at the time of the bushfire smoke pollution, giving a final total of 389 interviews.

Of the people surveyed, $70 \%$ reported at least one health effect due to the smoke, equating to approximately 30500 people in the Albury LGA. People reporting underlying health conditions such as cardiovascular or respiratory disease had higher rates of health effects with the highest rate in people reporting asthma (Table 1). $5 \%$ of respondents reported seeking medical attention because of the smoke.

People in the 40-74 years age group reported higher rates of health effects (Table 2). Over $74 \%$ of people surveyed reported that they were aware of the health advisories with television being the most likely source. Across most age groups, there were similar rates for people having seen, heard or read the public health advisories, although a lower rate in the over 75-years age group was reported (Table 2).

Of the people who reported being aware of the advisories, $53.5 \%$ stated that the main message was to remain indoors

Table 2. Percentage of people with symptoms, due to smoke exposure and people who were aware of health advisories by age group during a smoke event in Albury, NSW, January-February 2003

\begin{tabular}{|c|c|c|c|c|c|c|c|}
\hline \multirow[t]{2}{*}{ Factor } & \multicolumn{6}{|c|}{ Age group (years) (\%) } & \multirow{2}{*}{$\begin{array}{c}\text { All (\%) } \\
n=389\end{array}$} \\
\hline & $0-15^{a}$ & $16-24$ & $25-39$ & $40-59$ & $60-74$ & $75+$ & \\
\hline Any symptoms & 58.4 & 67.6 & 71.1 & 79.7 & 80.3 & 64.0 & 70.4 \\
\hline Saw, heard or read advisories ${ }^{b}$ & 74.1 & 72.8 & 78.6 & 74.4 & 75.4 & 57.7 & 74.2 \\
\hline - Television & 72.3 & 72.8 & 55.8 & 51.6 & 52.9 & 40.1 & 67.6 \\
\hline - Radio & 55.5 & 51.9 & 57.7 & 35.9 & 36.7 & 31.9 & 52.9 \\
\hline - Newspaper & 38.5 & 31.6 & 40.3 & 35.5 & 26.4 & 36.4 & 40.9 \\
\hline
\end{tabular}


with a further $24.5 \%$ reporting that the advisories suggested reducing or avoiding outdoor activity. When asked who the advisories were aimed at, $65.5 \%$ of people reported "the whole community" or similar while $31.9 \%$ reported "people with respiratory problems" (multiple responses allowed).

Over $70 \%$ of people surveyed reported changing behaviour during the smoke event. People who saw, heard or read the advisories were significantly more likely to report behaviour change than those who did not (odds ratio $(\mathrm{OR})=2.74 ; 95 \%$ confidence interval (CI) 1.50-5.02) (Table 3). The highest rate of behaviour change was reported by parents of children less than 16 years of age.

Table 3. Reported behaviour change in relation to awareness of health advisories during a smoke event in Albury, NSW, January-February 2003

\begin{tabular}{|c|c|}
\hline Behaviour change and advisories & $\%$ \\
\hline \multicolumn{2}{|l|}{ People who saw, heard or read advisories ${ }^{a}$ : } \\
\hline Changed behaviour - due to advisories & 57.3 \\
\hline Changed behaviour - due to smoke & 18.7 \\
\hline $\begin{array}{l}\text { Total who saw, heard or read advisories and } \\
\text { changed behaviour }\end{array}$ & 76.0 \\
\hline \multicolumn{2}{|l|}{ People who did not see, hear or read advisories ${ }^{\mathrm{b}}$ : } \\
\hline Changed behaviour - due to smoke & 53.6 \\
\hline \multicolumn{2}{|l|}{ Total populationc: } \\
\hline Changed behaviour - due to advisories & 42.5 \\
\hline Changed behaviour - due to smoke or advisories & 70.2 \\
\hline \multicolumn{2}{|c|}{$\begin{array}{l}\text { aPercentages calculated on the } 296 \text { respondents who saw, heard or } \\
\text { read the advisories. } \\
\text { bPercentages calculated on the } 93 \text { respondents who did not see, } \\
\text { hear or read the advisories. } \\
\text { 'Percentages calculated on all } 389 \text { respondents. }\end{array}$} \\
\hline
\end{tabular}

Most people who reported behaviour change stated that they either stayed inside, reduced outdoor activity or prevented smoke getting into homes (Table 4). Similar responses were found regardless of reported awareness of advisories. Over $14 \%$ of respondents reported leaving the area during the smoke event.

\section{Discussion}

This study demonstrates the widespread impact of an extreme bushfire smoke pollution event on a community. The symptoms reported by the respondents are consistent with other studies, as is the finding of increased reported symptom rates in those with existing cardiovascular and respiratory conditions. ${ }^{10-13}$ Public health advisories disseminated through mainstream media supported behaviour change to reduce exposure to bushfire smoke. These findings are also consistent with other studies. ${ }^{12,13}$

The survey of Albury residents was completed within 3 weeks of the particulate levels returning to normal. The timeliness of the survey should have served to minimise the possibility of recall bias. Due to extensive smoke pollution in southern NSW, it was assumed that the Albury LGA (an area of $106 \mathrm{sq} \mathrm{km}$ at the time) experienced uniform levels of pollution.

Public health advisories stated that symptoms related to smoke exposure included sore and itchy eyes, headache and sore throat, which may have served to influence the recall of symptoms reported. In interpreting the results of this survey, caution is appropriate since symptoms, exposures and behaviours were self-reported.

Despite the extreme pollution levels and the high proportion of residents experiencing symptoms, a small proportion of respondents reported seeking treatment for symptoms

Table 4. Actions taken due to health advisories and/or smoke during a smoke event in Albury, NSW, January-February 2003

\begin{tabular}{|c|c|c|c|c|}
\hline Action $^{a}$ & $\begin{array}{l}\text { Due to advisories } \\
(\%)\end{array}$ & $\begin{array}{l}\text { Due to smoke: saw, } \\
\text { heard or read } \\
\text { advisoriesc }(\%)\end{array}$ & $\begin{array}{l}\text { Due to smoke: did not } \\
\text { see, hear or read } \\
\text { advisories }^{\mathrm{d}}(\%)\end{array}$ & All (\%) \\
\hline Reduced outdoor activities & 52.0 & 62.3 & 51.6 & 54.0 \\
\hline Closed windows and doors & 45.1 & 40.9 & 44.0 & 44.0 \\
\hline Dried clothes inside & 17.7 & 26.9 & 13.8 & 18.7 \\
\hline Travelled out of area & 11.7 & 23.3 & 13.8 & 14.4 \\
\hline Used ceiling fans & 10.5 & 14.9 & 2.9 & 9.9 \\
\hline Other & 10.0 & 1.0 & 3.4 & 8.2 \\
\hline Wore a mask & 8.1 & 3.5 & 1.3 & 5.9 \\
\hline Increased regular medication & 2.3 & 0.0 & 1.3 & 1.6 \\
\hline Commenced taking medication & 1.5 & 0.0 & 0.0 & 0.9 \\
\hline \multicolumn{5}{|c|}{$\begin{array}{l}\text { aMultiple responses allowed. } \\
\text { bPercentages based on } 162 \text { people who changed behaviour due to advisories. } \\
\text { cPercentages based on } 52 \text { people who saw, heard or read advisories but changed behaviour due to smoke (not advisories). } \\
\text { dPercentages based on } 51 \text { people who changed behaviour due to smoke, but did not see, hear or read advisories. }\end{array}$} \\
\hline
\end{tabular}


associated with the smoke pollution. Mott et al. reported that medical clinic visits for respiratory illness increased by $52 \%$ during a bushfire smoke pollution event lasting 70 days with $\mathrm{PM}_{10}$ levels exceeding $500 \mu \mathrm{g} / \mathrm{m}^{3}$ on 2 days. ${ }^{12}$

The relatively simple mitigation measures of remaining indoors and reducing outdoor physical activity achieved high recall rates and represented the main reported behaviour changes. Fine particles can penetrate houses, with the extent of indoor pollution dependent on the air exchange rate. Penetration of particles into houses can be reduced by keeping doors and windows closed and using air conditioners with efficient filters. ${ }^{14}$

The benefit of masks in mitigating the effect of smoke pollution remains uncertain. Kunzli et al. reported that wearing masks during a smoke pollution event had a beneficial effect. ${ }^{13}$ Mask use was reported to be ineffective and positively associated with outdoor exposure by Mott et al. who suggested that inconsistent use of masks and lack of appropriate fit testing as well as the variability in the effectiveness of masks chosen for use, may have been contributing factors to mask failure. ${ }^{12}$

The issuing of health advisories based on alert guidelines during bushfire smoke pollution events has a number of limitations. First, the daily average $\mathrm{PM}_{10}$ result relates to the previous 24-hour period, not the current situation. Second, during the event in Albury, conditions changed rapidly depending on the prevailing winds. For example on one day, the hourly average $\mathrm{PM}_{10}$ result was $57 \mu \mathrm{g} / \mathrm{m}^{3}$ at $7 \mathrm{am}, 320 \mu \mathrm{g} / \mathrm{m}^{3}$ at $9 \mathrm{am}$ and $780 \mu \mathrm{g} / \mathrm{m}^{3}$ at $11 \mathrm{am}$. Framing advisory information according to the categories was useful as pollution was increasing; however, when extreme pollution levels were reached and conditions changed quickly, the categories were irrelevant. Based on World Health Organization guidelines, public health staff undertook a rapid correlation of hourly $\mathrm{PM}_{10}$ results with visibility of known markers. ${ }^{14}$ Further research is required to examine the validity and utility of visibility estimates in supporting public health advisories on bushfire smoke pollution.

\section{Acknowledgments}

The authors acknowledge the funding provided through the Environmental Health Branch of the NSW Department of Health for the CATI survey and Dr Vicky Sheppeard and Ms Margo Barr for their assistance with the survey. The authors acknowledge the NSW Department of Environment and Climate Change for the provision of air quality data.

\section{References}

1. Naeher LP, Brauer M, Lipsett M, Zelikoff JT, Simpson CD, Koenig JQ et al. Woodsmoke Health Effects: A Review. Inhal Toxicol 2007; 19: 67-106. doi:10.1080/08958370600985875

2. Bushfire Cooperative Research Centre and Australasian Fire Authorities Council. Fire Note: Climate Change and its impact on the management of bushfire. Issues 4. September 2006. Available from: http://www.bushfirecrc.com/publications/ downloads/Firenote_climate190906.pdf (Cited 7 July 2008.)

3. Churches T, Corbett S. Asthma and air pollution in Sydney. $N S$ W Public Health Bull 1991; 2: 72-3. doi:10.1071/NB91035

4. Cooper CW, Mira M, Danforth M, Abraham K, Fasher B, Bolton P. Acute exacerbations of asthma and bushfires. Lancet 1994; 343: 1509. doi:10.1016/S0140-6736(94)92621-2

5. Smith M, Jalaludin B, Byles J, Lim L, Leeder SR. Asthma presentations to emergency departments in Western Sydney during the January 1994 bushfires. Int J Epidemiol 1996; 25: 1227-36. doi:10.1093/ije/25.6.1227

6. Johnston FH, Webby RJ, Pilotto LS, Bailie RS, Parry DL, Halpin SJ. Vegetation fires, particulate air pollution and asthma: A panel study in the Australian monsoon tropics. Int J Environ Health Res 2006; 16: 391-404. doi:10.1080/09603120601093642

7. Australian Bureau of Statistics. Basic Community Profile, Albury LGA. Catalogue Number 2001.0. Canberra.

8. Government NSW. Air pollution Sydney: NSW Department of Health. Available from: http://www.health. nsw.gov.au/ publichealth/environment/air/air_pollution.asp (Cited 7 July 2008.)

9. Government NSW. About air quality monitoring. Sydney: Department of Environment and Climate Change. Available from: http://www.environment.nsw.gov.au/AQMS/aboutaqi. htm\#AQI (Cited 7 July 2008.)

10. Long W, Tate RB, Neuman M, Manfreda J, Becker AB, Anthonisen NR. Respiratory symptoms in a susceptible population due to burning of agricultural residue. Chest 1998; 113: 351-7. doi:10.1378/chest.113.2.351

11. Aditama TY. Impact of haze from forest fire on respiratory health: Indonesian experience. Respiriology 2000; 5: 169-74. doi:10.1046/j.1440-1843.2000.00246.x

12. Mott JA, Meyer P, Mannimo D, Redd SC, Smith EM, GotwayCrawford C et al. Wildland forest fire smoke: health effects and intervention evaluation, Hoopa, California, 1999. West $J$ Med 2002; 176: 157-62. doi:10.1136/ewjm.176.3.157

13. Kunzli N, Avol E, Wu J, Gauderman WJ, Rappaport E, Millstein J et al. Health effects of the 2003 southern California wildfires on children. Am J Respir Crit Care Med 2006; 174: 1221-8. doi:10.1164/rccm.200604-519OC

14. World Health Organization. Health guidelines for vegetation fire events. World Health Organization 1999. Available from: http://www.crid.or.cr/digitalizacion/pdf/eng/doc12962/ doc12962.htm (Cited 7 July 2008.) 


\section{Urbanism, climate change and health: systems approaches to governance}

\section{Anthony G. Capon ${ }^{\mathrm{A}, \mathrm{D}}$, Emma S. Synnott ${ }^{\mathrm{B}}$ and Sue Holliday ${ }^{\mathrm{C}}$}

\author{
ANational Centre for Epidemiology and Population Health, \\ Australian National University \\ B Arup (global firm of designers, engineers, planners and \\ business consultants) \\ CStrategies for Change (urban strategy consultancy) \\ DCorresponding author. Email: tony.capon@anu.edu.au
}

\begin{abstract}
Effective action on climate change health impacts and vulnerability will require systems approaches and integrated policy and planning responses from a range of government agencies. Similar responses are needed to address other complex problems, such as the obesity epidemic. Local government, with its focus on the governance of place, will have a key role in responding to these convergent agendas. Industry can also be part of the solution - indeed it must be, because it has a lead role in relevant sectors. Understanding the co-benefits for health of climate mitigation actions will strengthen the case for early action. There is a need for improved decision support tools to inform urban governance. These tools should be based on a systems approach and should incorporate a spatial perspective.
\end{abstract}

\section{The challenge}

This paper argues for a systems oriented governance model to integrate responses to health and climate change in an urban context. Health impacts of climate change arise from direct and indirect pathways, including extreme weather, changing patterns of infectious disease, effects on fresh water supplies and food yields, loss of livelihoods, displacement of vulnerable populations and impaired functioning of ecosystems. ${ }^{1}$ Regions and communities will experience differing impacts of climate change, based on varying exposure and sensitivity. Vulnerability to health impacts is also a consequence of adaptive capacity. ${ }^{2}$
A recent report from the United Kingdom (UK) on tackling the obesity epidemic highlights similarities with tackling climate change - 'both need whole societal change with cross governmental action and long-term commitment' ${ }^{3}$ Importantly, the underlying causes of anthropogenic climate change are inextricably linked with the underlying causes of the obesity epidemic.

Our modern way of life is changing the climate and making us sick. ${ }^{4}$ Addressing the underlying causes of these related challenges requires a convergent approach where we recognise a common policy locus in the places in which we live. This includes organising our response on a spatial basis and improved urban governance. Traditional approaches to health and urban planning tend not to speak the same language and there is a need to conceptually align their agendas, developing integrated approaches to the planning, development and management of the places in which we live - to ensure these are healthy and sustainable places.

\section{Governance, systems thinking and virtuous cycles}

Governance refers to processes to ensure the effective management of a project, organisation or system. In Australia, cities and towns - the places where most of us now live; and places that can foster economic development are governed through a multitude of structures, regulations and policies. Now, more than ever before, we require a common approach to the city, as the focus of sustainable living in its widest sense. Our governments (local, state and national) should lead on the governance of towns and cities; and they should do so in partnerships with industry and the wider community. The challenge of achieving integrated health and sustainability outcomes is how to embed this way of thinking into the daily business of governance, whether this is a strategic policy or a spatial project.

There are lessons for Australia from the approach to sustainability governance taken in the UK. Mechanisms include formal sustainability commissions with statutory reporting responsibilities; sustainable development frameworks to guide strategic and spatial policy at national, regional and local levels; independent assurance of sustainability goals; and statutory requirements to consider sustainability in policy and planning decisions. The London experience is instructive. The Greater London Authority Act requires the Mayor to meet a statutory duty 
to 'promote health, equality of opportunity and sustainable development'. The London Sustainable Development Commission was established in 2002 to advise the Mayor on developing the city as an exemplary sustainable city and to assist in fulfilling the Mayor's statutory duty. The Commission designed an integrative sustainable development framework by which it could appraise decisions and drive policy development; taking decision-makers beyond an approach that simply divided policy initiatives into the usual social, environmental and economic silos. ${ }^{5}$ This framework is based on the concept of 'virtuous cycles thinking' where co-benefits are identified and actively pursued (Figure 1). ${ }^{6,7}$

Embedding sustainability into decision-making can be significantly bolstered by formal governance structures that incorporate external reporting. The UK Sustainable Development Commission now reports annually on progress of the government estate in meeting its sustainability targets, including its commitment to be carbon neutral by $2012 .^{8}$

Whether planning for the aged, the ageing or for the next generation, the way we conceive and design our cities will influence the ability of the population to choose the way it lives. Rather than thinking about zonings and land uses, a people-centred approach to planning will lead to different outcomes from those we have today. Starting with a premise of reshaping the city around how an individual and their family use the city for daily needs, a different solution emerges. If a healthy way of life is at the core of that thinking, then a more self-contained model of neighbourhood and region is the outcome. Walking to school, the local shops, accessing public transport easily for the journey to work and for daily needs and providing cycleways to local recreation and community activities are some design requirements for a healthy city. To achieve this end, a more integrated approach to planning is needed considering environment, transportation, work and people. The approach should consider how people will inhabit their place, and what their habits (behaviours) mean for their health and wellbeing, and for the health of the environment.

\section{The current situation}

There are myriad sustainable urbanism demonstration projects in Australia and abroad, both greenfield and retro-fit. Some examples include: Christie Walk, an ecohousing development in Adelaide; eco-towns and cities planned in the UK, China and the Middle East; and Samso,

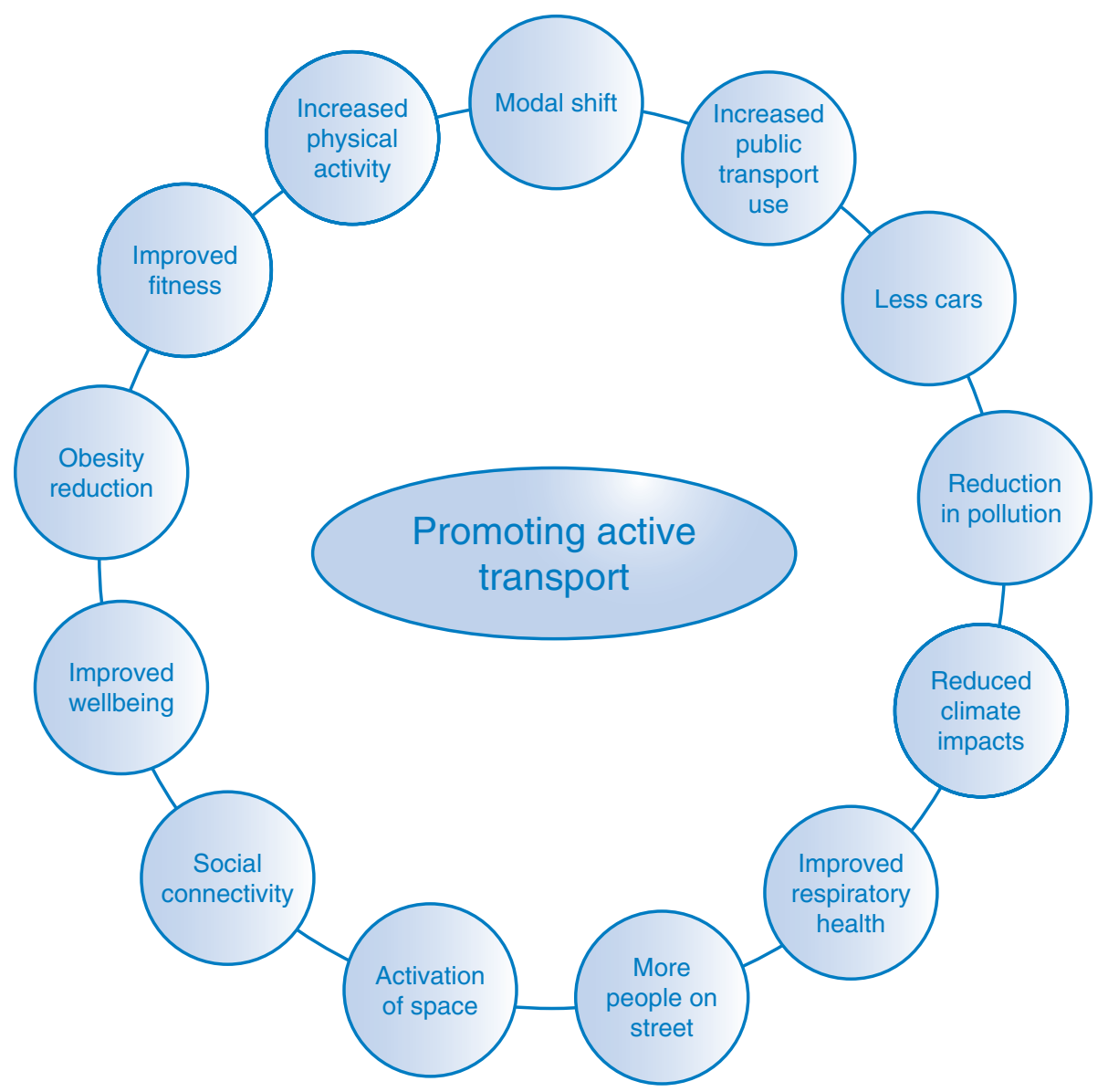

Figure 1. Representation of the benefits of active transport as a virtuous cycle. 
an island in Denmark, which is currently the largest carbon-neutral settlement in the world. An important lesson from Samso is that people want to be involved in decision-making and innovation; something oft-cited as beneficial, but rarely achieved.

The Copenhagen Agenda for Sustainable Cities is a Danish initiative in advance of the United Nations' Climate Conference later in 2009. The Agenda advocates improved city planning, development and management as a strategy for tackling climate change and other pressing global challenges, such as poverty and epidemic chronic disease. The Scandinavian thinktank, Monday Morning, canvassed 50 urban experts and identified 10 principles for sustainable city governance (Box 1). In moving forward with this initiative, it will again be important to ensure integrative approaches to achieve sustainable and healthy cities.

The Western Sydney Regional Organisation of Councils has recently developed an Agenda for Sustainability and Wellbeing, which argues that social, environmental, cultural and economic issues need to be considered together in an ecological way. This agenda arises from a view that cities are 'human ecological systems' that are supported by, and integrated with, 'natural ecological systems'. The sustainability of the city, and the health and wellbeing of the population, are seen as a consequence of interaction between these ecological systems. The agenda seeks to widen the focus of sustainability from individual behaviour change (such as reducing household water and energy use) to structural changes in the places in which people socialise, live and work.

Healthy Spaces and Places is a project that aims to promote the development of built environments, which facilitate lifelong active living, and promote good health outcomes, for all Australians. It is an initiative of the Planning Institute of Australia, in partnership with the National Heart Foundation and the Australian Local Government Association, and with the support of the Australian Government Department of Health and Ageing. It builds on the Healthy by Design initiative of Institute's Victorian Division. ${ }^{9}$

Health impact assessment methods have been used to assess impacts and vulnerability to climate change. ${ }^{2}$ This methodology is a useful decision support tool for policy and planning responses to climate change. An important challenge is to ensure that such assessments are informed by a systems perspective.

\section{Suggested actions}

First, there is a case for a paradigm shift in current sustainability discourse. The three pillars of sustainability environmental, social and economic (often called the
Box 1. Copenhagen agenda for sustainable cities: 10 principles for sustainable city governance
1. Rediscover the city
2. Redefine city value
3. Involve everyday experts
4. Break down silos
5. Redistribute urban decision-making
6. De-design urban planning
7. Promote corporate urban responsibility
8. Go global
9. Embrace chaos, crisis and change
10. Encourage passion in urban leadership
Full details of the 10 principles are available from: http://mm.dk/filer/10principles.pdf

\section{Box 2. Financial governance of urban development: a putative role for retail banks}

Australia's retail banks lend money to many people to finance the purchase of their homes. The same banks also lend money (often large amounts) to industry to finance the development of land for suburban housing and apartments. The banks seem well-placed to assume a role in the governance of land development. If housing (free standing houses, townhouses and apartments) is developed in ways that minimise energy and water consumption and enable residents to have ready access to their daily needs (schools, shops, services, jobs, recreation, transport), the ongoing running-costs of housing will be reduced (e.g. lower energy and water bills, and transport costs). This is of interest to the banks because it should make the home loans more secure. The home loan customer is more likely to be able to meet their repayments; and the value of the housing is likely to increase over time because it will remain an attractive place to live.

Australia's retail banks should consider applying conditions to loans for housing development, and perhaps providing interest rate incentives to developers and home buyers, for healthy and sustainable choices. Certainly, this could not be implemented without the support of government because transport, in particular mass transit, is a key to healthy and sustainable urban development and requires government commitment.

triple-bottom-line) - are means rather than ends. ${ }^{10}$ Environmental, social and economic circumstances are all important determinants of human life experience and, ultimately, physical and mental health and wellbeing. Health should therefore be considered a primary outcome in all sustainability policy and planning.

Second, there is a need to apply what we already know about human-environment interactions to the planning, development and management of the places in which we live. This, and further research, should be informed by a systems understanding of health and wellbeing and should identify roles and responsibilities for industry (Box 2) and acknowledge the contribution of civil society. ${ }^{3}$ 
Table 1. Some necessary actions to re-orient towards systems approaches to urban governance

\begin{tabular}{|c|c|}
\hline Necessary action & Who is responsible for the action? \\
\hline $\begin{array}{l}\text { Strengthen emphasis on systems methods in the education } \\
\text { of public health and planning workforce }\end{array}$ & Universities with public health and planning programs \\
\hline $\begin{array}{l}\text { Develop workforce capacity to use systems methods } \\
\text { in problem-solving }\end{array}$ & Professional organisations, government, industry \\
\hline $\begin{array}{l}\text { Foster inter-disciplinary and trans-disciplinary approaches } \\
\text { in planning, implementation and evaluation of policy } \\
\text { and other interventions }\end{array}$ & All stakeholders \\
\hline $\begin{array}{l}\text { Demonstrate application of systems approaches in relevant } \\
\text { projects }\end{array}$ & Industry, government and community organisations \\
\hline $\begin{array}{l}\text { Incorporate systems science approaches in impact assessment } \\
\text { of projects, policies and programs }\end{array}$ & Commissioning organisations and proponents \\
\hline $\begin{array}{l}\text { Vision and leadership valuing systems approaches and } \\
\text { adaptive management }\end{array}$ & Business leaders, community leaders, elected representatives \\
\hline
\end{tabular}

Third, there is a need for workforce development and capacity building. Professional bodies, such as the Planning Institute of Australia, the Public Health Association of Australia and the Australasian Faculty of Public Health Medicine are responding to this challenge. The University of New South Wales' teaching program in Healthy Urban Planning provides opportunities for interprofessional learning for health and planning students. ${ }^{11}$ Planning and public health courses should embrace systems methods and ensure future professionals are equipped to deal with emerging challenges.

Finally, there is a need for improved decision support tools, for example, audit tools that incorporate both a systems perspective and a spatial focus and acknowledge the need for effective governance approaches. These can build on existing methods and should accommodate quantitative and qualitative information (Table 1).

\section{Meeting the challenge}

Climate change and obesity have been characterised as 'wicked policy problems' - problems that cannot be successfully treated with traditional linear, analytical approaches. ${ }^{12,13}$ That said, we must not be overwhelmed by the complexity of these challenges. Systems understanding can help us navigate a path through the complexity. Without such an approach there appears to be no clear governance strategy for addressing the spatial and policy intersection between the structure of our cities, trends in health outcomes and the carbon intensity of our way of life. We have to be prepared to make decisions and, in doing so, allow ourselves to make mistakes. Provided we learn as we go, we will make progress.

\section{Acknowledgment}

The authors thank Liam Ryan for assistance with Figure 1. Anthony Capon is partly supported by funding from an NHMRC Australia Fellowship award to Professor AJ McMichael.

\section{References}

1. McMichael AJ, Friel S, Nyong A, Corvalan C. Global environmental change and health: impacts, inequalities and the health sector. BMJ 2008; 336: 191-4. doi:10.1136/bmj.39392. 473727.AD

2. Department of Health. Western Australia. Health impacts of climate change: Adaptation strategies for Western Australia. Lead authors: Spickett J, Brown H, Katscherian D. Perth: Department of Health; 2008. Available from: http://www. health.wa.gov.au/envirohealth/planning/docs/Health_Impacts_ of_Climate_Change.pdf (Cited 26 October 2008.)

3. Government Office for Science. Foresight. Tackling obesities: Future choices - project report. London: Department for Innovation, Universities and Skills; 2007.

4. Oxford Health Alliance. The Sydney Resolution. London: Oxford Health Alliance; 2008. Available from: http://www. oxha.org/meetings/08-summit/sydney-resolution (Cited 26 October 2008.)

5. London Sustainable Development Commission. A sustainable development framework for London. London: Mayor of London; 2003. Available from: http://www.londonsdc.org/ documents/1sdc_framework.pdf (Cited 26 October 2008.)

6. Stott R. Implications for health in a low carbon (Contract and Converge) world. J Epidemiol Community Health 2006; 60: 828 .

7. Birkeland J. Positive Development: From Vicious Circles to Virtuous Cycles through Built Environment Design. London: Earthscan; 2008.

8. UK Sustainable Development Commission. Watchdog. London: Sustainable Development Commission. Available from: http://www.sd-commission.org.uk/pages/watchdog.html (Cited 26 October 2008.)

9. Sutherland E, Carlisle R. Healthy by Design: an innovative planning tool for the development of safe, accessible and attractive environments. N S W Public Health Bull 2007; 18: 228-31. doi:10.1071/NB07030

10. McMichael AJ. Population health as the 'bottom line' of sustainability: a contemporary challenge for public health researchers. Eur J Public Health 2006; 16: 579-81. doi:10.1093/eurpub/ck1102 
11. Thompson S, Romero V. Healthy planning: Bringing interdisciplinary research into planning education. Paper presented at the Conference of the Australian and New Zealand Association of Planning Schools, Dunedin; 2007. Abstract available from: http://www.geography.otago.ac.nz/Geography/ ANZAPS_Abstracts.html (Cited 26 October 2008.)

12. Australian Public Service Commission. Tackling wicked problems: A public policy perspective. Canberra:
Commonwealth of Australia; 2007. Available from: http://www.apsc.gov.au/publications07/wickedproblems2.htm (Cited 26 October 2008.)

13. Rittel H, Webber M. Dilemmas in a general theory of planning. Policy Sci 1973; 4: 155-69. doi:10.1007/BF01405730 


\section{Hepatitis A:Wallis Lake revisited}

\section{Katina Kardamanidis ${ }^{\mathrm{A}}$, Stephen J. Corbett ${ }^{\mathrm{B}}$ and Anthony P. Zammitt ${ }^{\mathrm{C}}$}

${ }^{\mathrm{A}}$ NSW Public Health Officer Training Program, NSW Department of Health

${ }^{\mathrm{B}}$ Centre for Population Health, Sydney West Area Health Service ${ }^{\mathrm{C}} \mathrm{NSW}$ Shellfish Program, NSW Food Authority

In 1997, Wallis Lake, a major oyster-growing estuary on the mid-north coast of New South Wales (NSW), was the source of a large hepatitis A outbreak caused by contaminated oysters. Ten years on, we revisited the epidemiology and clinical presentation of hepatitis A, appraised the environmental controls on oyster leases since the Wallis Lake outbreak, and placed shellfish quality management in an historic, cultural and economic context.

The hepatitis A virus is transmitted via the faecal-oral route and can cause a range of symptoms including malaise and diarrhoea, acute hepatitis with jaundice, and sudden and severe liver failure. Patients usually recover completely without sequelae or recurrences, and develop lifelong immunity. ${ }^{1}$ Hepatitis A is a disease often associated with poor environmental sanitation, with water and food as the principle vehicles of transmission. In Australia, the quality of water and sanitation is generally good and not an important cause of hepatitis A virus transmission. In NSW, $50 \%$ of people notified with hepatitis A between 2002 and 2006 reportedly acquired the infection during travel to endemic areas. ${ }^{2}$ Travellers born in endemic countries returning to their country of origin to visit friends and relatives were at highest risk of infection. ${ }^{2}$

However, the outbreak in 1997 that resulted in 422 cases of hepatitis A in NSW was traced to oysters from Wallis Lake. ${ }^{3}$ An environmental investigation by NSW Health found the lake contaminated with human faecal and nutrient pollution from unsewered townships, agricultural areas, waterway users and run-off from a large urbanised area. In response to the outbreak, a range of local and state government agencies collaborated in estuary and catchment remediation works. Public toilets were built for the boating public, devices were installed to improve stormwater management, sewerage was provided to several townships, litter baskets were added in stormwater drains, and eight wetlands were constructed to serve as a filter for the water reaching the estuary. The remediation works greatly improved the quality of the Wallis Lake water and in 2004 the local council was awarded the Thiess Riverprize for best practice in river and catchment management and environmental repair in Australia. ${ }^{4}$
To help protect the public from consuming contaminated shellfish, the NSW Food Authority runs the NSW Shellfish Program. ${ }^{5}$ The program aims to prevent the harvest of contaminated shellfish by determining the classification of specific harvest areas as either 'approved' for harvest and direct sale; 'restricted' until shellfish are depurated (i.e. placed in clean water so that they can release accumulated micro-organisms into the surrounding water) or relayed to an approved harvest area prior to sale; or 'prohibited' from harvest at any time. The classifications are determined by continuous risk assessment through surveys of potential pollution sources (such as sewage treatment plants, boats and construction sites), and sanitary surveys of the shoreline, water quality and shellfish. In addition, harvest areas can be closed immediately if thresholds (for example, rainfall or salinity thresholds) are exceeded.

The Wallis Lake hepatitis A outbreak demonstrated the close relationship between coastal development, sewage management, infectious diseases and human health. During this outbreak, the financial journalist Max Walsh drew attention to a book, The French, the English and the Oyster written by the British economist, Robert Neild. ${ }^{6}$ An oyster lover, the author examined why, in the face of similar threats, the French oyster industry had survived and thrived while the English industry had not. He concluded that the French mercantilist, economic and centralist political traditions enabled successive French governments to exercise effective power over such things as the distribution and location of oyster leases, the prohibition of harvesting at certain times and the management of human waste. In England on the other hand, the laissez faire economic ideology permitted the oyster industry to wither as the inevitable effects of human development and oyster-related foodborne outbreaks became manifest.

The Wallis Lake outbreak was a stark reminder of the inherent conflict between urban and rural development and oyster growing. The combination of environmental measures and the NSW Shellfish Program has been a successful public health and commercial response to the hepatitis A outbreak. In 2008, more than 10 years after the outbreak, the Wallis Lake oyster industry is thriving, producing 30\% of Sydney rock oysters in 2007 worth an estimated \$14 million, and winning the Sydney Rock Oyster People's Choice Award for tastiest oysters. ${ }^{7}$

\section{References}

1. National Health and Medical Research Council. The Australian Immunisation Handbook. 9th ed. Canberra: NHMRC; 2008. 
2. Ward K, McAnulty J. Hepatitis A: who in NSW is most at risk of infection? N S W Public Health Bull 2008; 19(1-2): 32-5. doi:10.1071/NB07100

3. Conaty S, Bird P, Bell G, Kraa E, Grohmann G, McAnulty JM Hepatitis A in New South Wales, Australia, from consumption of oysters: the first reported outbreak. Epidemiol Infect 2000; 124: 121-30. doi:10.1017/S0950268899003386

4. International Riverfoundation. The Thiess Riverprize. Available from: www.riverfoundation.org.au (Cited 11 September 2008.)
5. Food Authority NSW. NSW Shellfish Program. Available from: http://www.foodauthority.nsw.gov.au/industry/industry-sectorrequirements/shellfish/ (Cited 11 September 2008.)

6. Neild R. The English, the French and the Oyster. London: Quiller Press; 1995.

7. Sydney Morning Herald. 22 July 2008. "The world is now their oyster". Available from: http://www.smh.com.au/news/ national/the-world-is-now-their-oyster/2008/07/21/

1216492357295.html (Cited 11 September 2008.) 


\section{Communicable Diseases Report, NSW, November and December 2008}

\section{Communicable Diseases Branch NSW Department of Health}

For updated information, including data and facts on specific diseases, visit www.health.nsw.gov.au and click on Infectious Diseases or access the site directly at: http://www.health.nsw.gov.au/public health/infectious/index.asp.

Figure 1 and Tables 1 and 2 show reports of communicable diseases received through to the end of December 2008 in New South Wales (NSW).

\section{Pertussis (whooping cough)}

An outbreak of pertussis that commenced in northern NSW in late 2007 has continued to spread across NSW. In November and December, there were 1740 cases and 1989 cases respectively reported. A total of 8181 cases were reported in 2008, equivalent to 119 cases per 100000 people. This represents a significant increase since 2007 where 2097 cases were reported (30/100 000 people).

Cases under 1 year of age had the highest age-specific incidence (346 cases notified, which is equivalent to 386 cases per 100000 ). Many of these children were not yet immunised as the vaccine is routinely given at 2, 4 and 6 months of age. No deaths were reported in children or infants who are normally at greatest risk of severe morbidity and mortality from pertussis.

A second peak was seen in children aged around 14 years, where there were 293 cases reported (equivalent to an agespecific rate of 318 cases per 100000$)$. A school-based pertussis booster immunisation program is due to commence in 2009, targeting children in year 10 who will be aged around 15 years.

In recent months, the proportion of cases diagnosed using polymerase chain reaction (PCR) has increased substantially and the majority of cases are now diagnosed using PCR rather than by serology. This is likely to reflect the increased proportion of cases in younger age groups where PCR-based diagnosis is typical and clinicians have increased awareness of the availability and advantages of PCR tests over traditional serological testing methods.

Key public health messages for pertussis have included recommendations:

- to ensure that pertussis vaccines are given on time to babies at 2, 4 and 6 months and the booster is given to children at 4 years

- to inform the community about the adult booster vaccine for parents and carers of babies and young children, child-care workers and health-care workers

- to be alert for the clinical features of pertussis and seek medical assessment promptly; early diagnosis and treatment reduces the period of infectiousness

- to administer chemoprophylaxis to contacts where the case is likely to have significant contact with at-risk infants who are at greatest risk of severe disease.

\section{Enteric diseases}

In November and December 2008, NSW public health units investigated 61 outbreaks of gastroenteritis, including 47 where person-to-person transmission was likely and 14 suspected to be the result of foodborne transmission.

The 47 suspected person-to-person outbreaks affected a total of 569 people. Twenty-four occurred in aged-care facilities and affected 384 people, 11 occurred in hospitals and affected 109 people, 10 occurred in child-care centres and affected 66 people, and there were two outbreaks in other institutional settings affecting 10 people. Clinical specimens were submitted for testing from 21 of 47 (45\%) suspected person-to-person gastroenteritis outbreaks. Norovirus was identified in five outbreaks. The causative agent was not determined or reported for the remaining outbreaks.

Outbreaks suspected to be caused by food were commonly reported in November and December. These 14 outbreaks affected at least 146 people. Two of these outbreaks, where more than 20 people were infected with Salmonella, were associated with cakes containing raw egg mousse from the same bakery. The eggs were traced back to a farm where Salmonella was identified following an environmental investigation by the NSW Food Authority. The same egg farm was linked to a gastroenteritis outbreak earlier in 2008. Another Salmonella outbreak was related to deli 
meats purchased from a supermarket. Two outbreaks, affecting 20 people, were caused by Clostridium perfringens in curry meals.

The remaining outbreaks were small, affecting three and four people after restaurant meals. No pathogens were detected in any of these cases. The sites of the outbreaks were inspected and no known sources were identified.

\section{Shiga toxin-producing Escherichia coli and haemolytic uraemic syndrome}

Shiga toxin-producing Escherichia coli (STEC) are bacteria that can cause serious gastrointestinal disease characterised by diarrhoea, which in some cases can be bloody. In a small proportion of cases, STEC can progress to haemolytic uraemic syndrome (HUS), which results in kidney failure, bleeding and anaemia. Infections tend to increase in the warmer months. ${ }^{1}$

In November and December 2008, NSW public health units were notified of eight STEC (two serotype O157 and seven of unknown serotype) and six HUS cases (three were also STEC positive). Of the eight cases, ages ranged from 2 to 75 years. Six were female and two male. The HUS cases were in both children and adults over 40. This number of STEC and HUS cases is consistent with the seasonal increase seen at this time each year.

STEC infection can be transmitted through:

- eating contaminated food (undercooked hamburgers, unwashed salad, fruit, vegetables and unpasteurised milk or milk products)

- drinking or swimming in contaminated water
- person-to-person contact; for example, contact when changing a nappy with the faeces of a child with the infection

- contact with infected animals. $^{2,3}$

The most important ways to prevent infection with STEC and other foodborne diseases are to:

- cook hamburgers and sausages thoroughly to at least $71^{\circ} \mathrm{C}$. Although colour alone is not necessarily a good indicator, do not eat hamburgers or sausages if there is any pink meat inside

- wash hands well after handling raw meat

- use different knives and cutting boards for raw meat preparation and other food preparation

- wash raw vegetables and fruits thoroughly

- refrigerate perishable food until ready to eat - so that bacteria do not incubate out of the fridge

- wash hands well after touching animals or their faeces.

For more information see: http://www.health.nsw.gov.au/ publichealth/Infectious/a-z.asp

\section{References}

1. Tarr PI, Gordon CA, Chandler WL. Shiga-toxin-producing Esceherichia coli and haemolytic uraemic syndrome. Lancet 2005; 365: 1073-86.

2. Heymann D, ed. Control of Communicable Diseases Manual, 18th ed. Washington: American Public Health Association; $2004,160-4$.

3. Razzaq S. Hemolytic uremic syndrome: an emerging health risk. Am Fam Physician 2006; 74: 991-6. 
Figure 1. Reports of selected communicable diseases, NSW, January 2004 to December 2008, by month of onset. Preliminary data: case counts in recent months may increase because of reporting delays. Laboratory-confirmed cases only, except for measles, meningococcal disease and pertussis. BFV, Barmah Forest virus infection; RRV, Ross River virus infection; lab conf, laboratory confirmed; Men $\mathrm{Gp} C$ and $\mathrm{Gp} \mathrm{B}$, meningococcal disease due to serogroup $C$ and serogroup $B$ infection; other/unk, other or unknown serogroups.

NB: Multiple series in graphs are stacked, except gastroenteritis outbreaks.

NB: Outbreaks are more likely to be reported by nursing homes and hospitals than by other institutions.

\begin{tabular}{|lc|}
\hline \multicolumn{2}{|c|}{ NSW Population } \\
Male & $50 \%$ \\
$<5$ y & $7 \%$ \\
$5-24$ y & $27 \%$ \\
$25-64$ y & $53 \%$ \\
$65+y$ & $13 \%$ \\
Rural & $46 \%$ \\
\hline
\end{tabular}
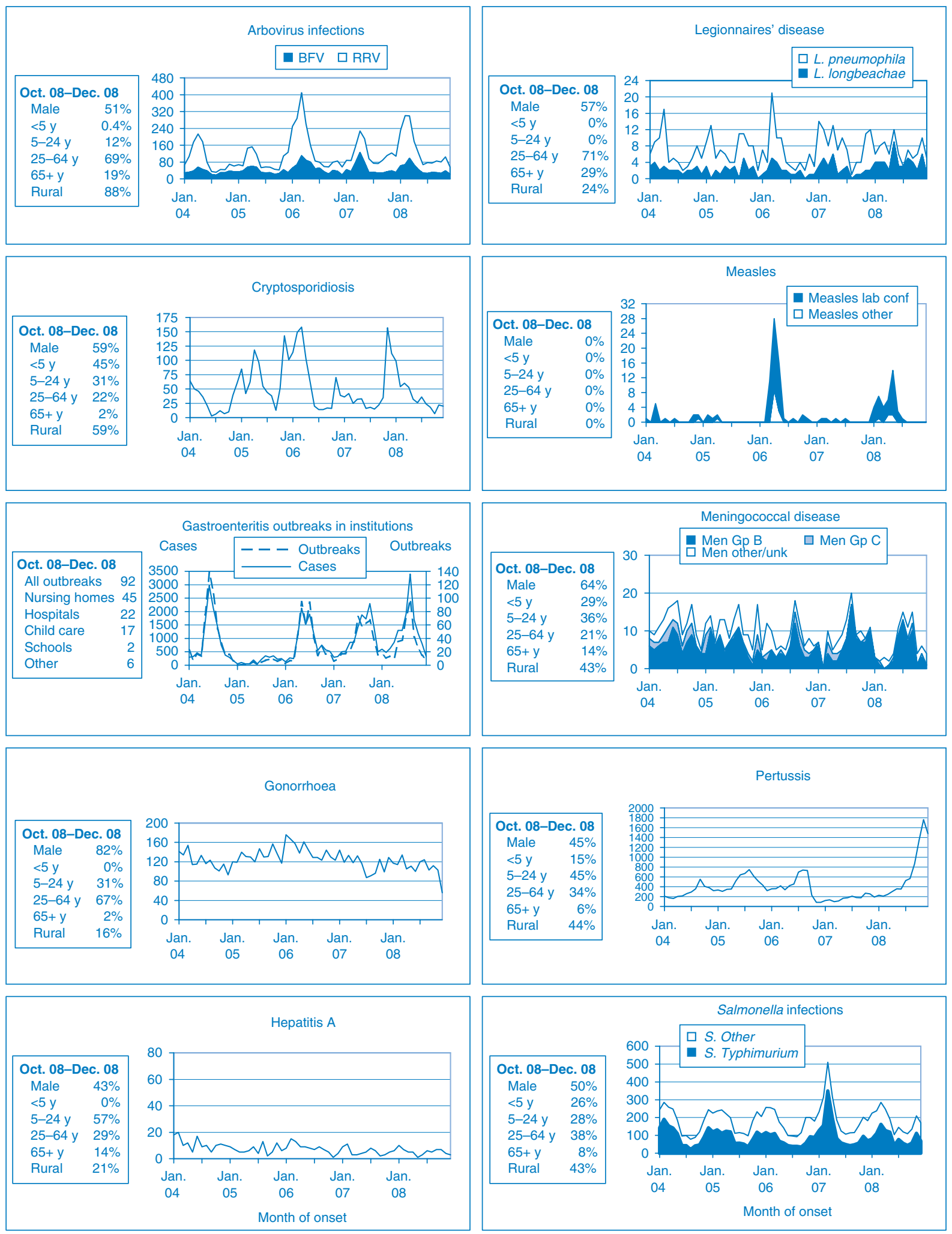


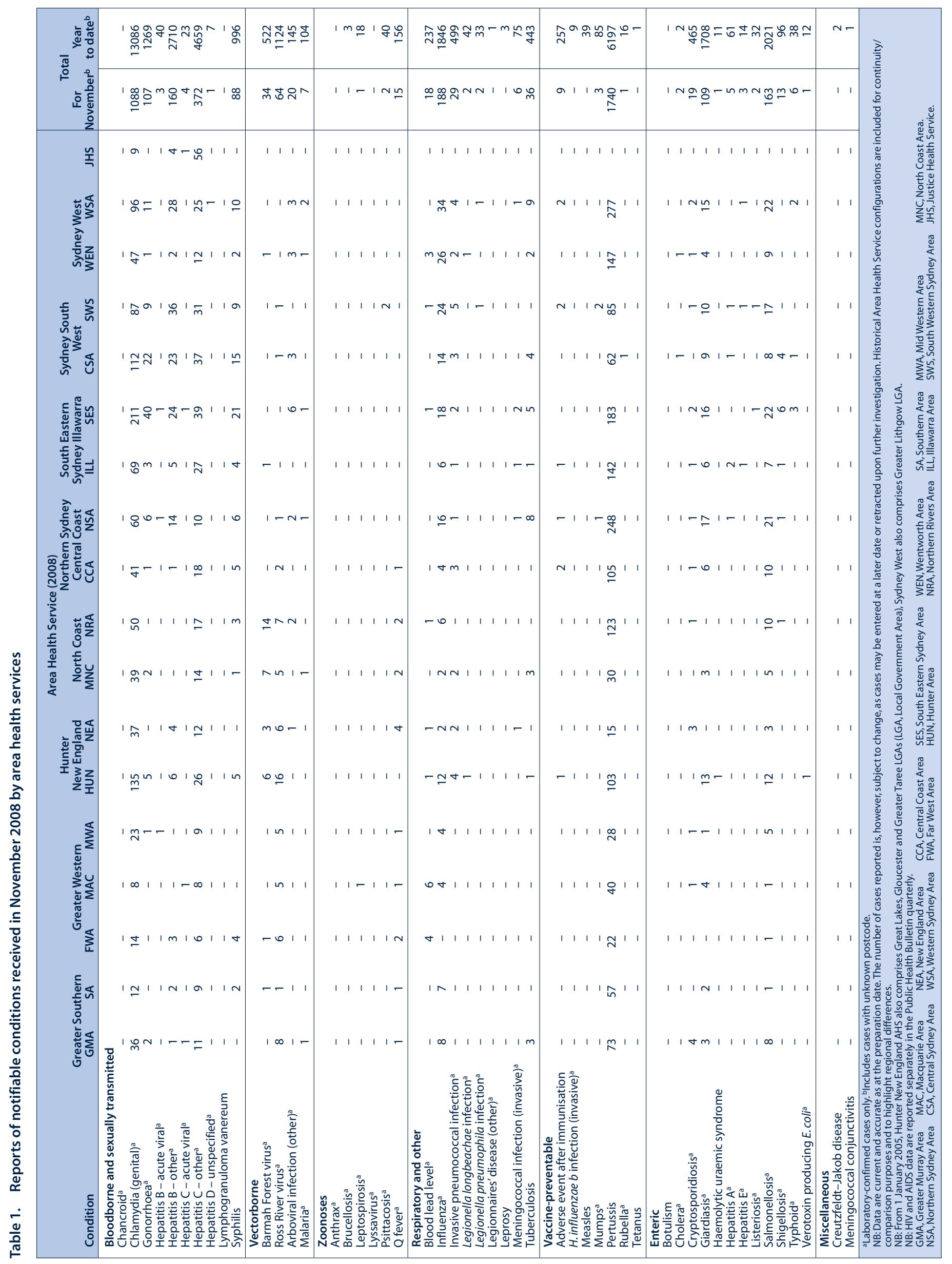




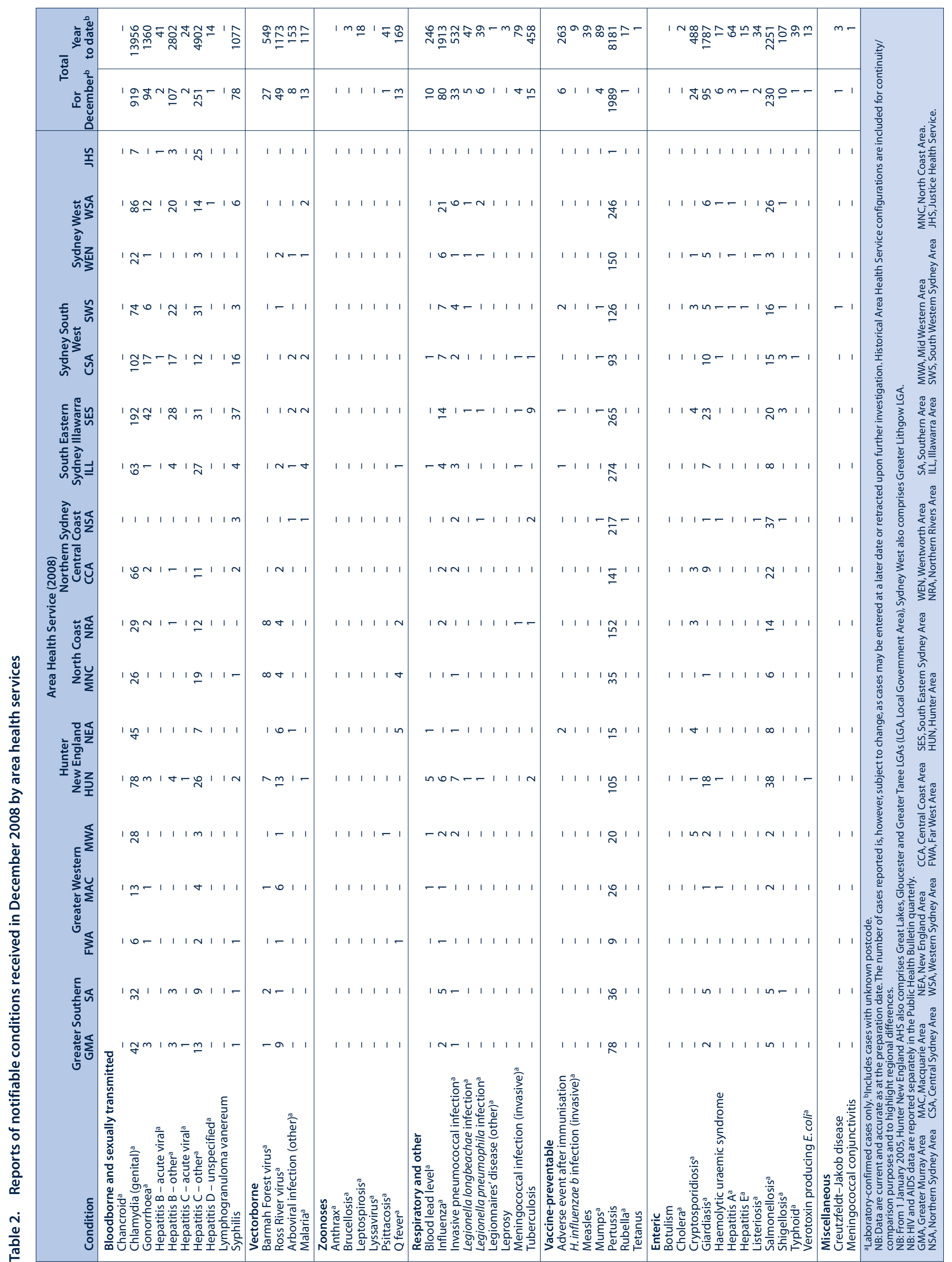




\section{Contents}

\section{Guest editorial}

1 Climate change: an emerging health issue

Introduces the articles in this issue, describing the health impacts of climate change and outlining some current actions in response to this emerging health issue.

\section{Anthony G. Capon, Elizabeth G. Hanna}

5 Climate change and health: impacts, vulnerability, adaptation and mitigation

Describes the public health implications of global climate change for Australia and how strategies for mitigation and adaptation can have direct co-benefits for the health of individuals and communities

Tord Kjellstrom, Haylee J. Weaver

10 Active travel: a climate change mitigation strategy with co-benefits for health

Summarises a number of NSW active travel initiatives as a response to global warming and the increasing imperative to change personal behaviour to slow the rate of climate change.

Chris E. Rissel

14 Functional foods and urban agriculture: two responses to climate change-related food insecurity

Reviews two strategies for dealing with climate changerelated food insecurity and argues that civic and urban agriculture presents an approach that is more connected to factors affecting diet and health.

Jane M. Dixon, Kelly J. Donati, Lucy L. Pike, Libby Hattersley
19 An extreme bushfire smoke pollution event: health impacts and public health challenges

Describes the role of public health in determining the health impact of smoke and the effectiveness of advisories during a severe bushfire smoke event.

Anthony Kolbe, Kim L. Gilchrist

24 Urbanism, climate change and health: systems approaches to governance

Argues for systems approaches and holistic urban governance to effectively address health impacts of climate change and other problems such as the obesity epidemic.

Anthony G. Capon, Emma S. Synnott, Sue Holliday

\section{Bug Breakfast in the Bulletin}

29 Hepatitis A:Wallis Lake revisited

Katina Kardamanidis, Stephen J. Corbett,

Anthony P. Zammitt

\section{Communicable Diseases Report, NSW}

31 November and December 2008

\section{NSW PUBLIC HEALTH BULLETIN}

The NSW Public Health Bulletin is a peer-reviewed journal produced by the NSW Department of Health and indexed in Medline. It has a NSW focus, however, it aims to support the practice of public health more broadly.

\section{Editors}

Dawn Simpson and Caron Bowen

\section{Editorial correspondence}

Please address all correspondence and submissions to:

The Editor, NSW Public Health Bulletin Locked Mail Bag 961

North Sydney NSW 2059 Australia

Email:phbulletin@doh.health.nsw.gov.au

Telephone: +61 294245876

Fax: +61 293919232

\section{Submission of articles}

The Bulletin accepts proffered and commissioned articles along with short reports, on all aspects of public health. Articles should be 1500-2000 words, not including tables and figures, and should include an abstract of up to 100 words. Articles should follow the journal style and layout as closely as possible, as described in the Instructions to Authors. Articles should be emailed in a Word for Windows format to: phbulletin@doh.health.nsw.gov.au, and should be accompanied by a covering letter signed by all authors and a License to Publish. The Instructions to Authors, License to Publish and other useful information can be downloaded from the Bulletin website.

\section{Distribution}

The Bulletin is freely available from the Bulletin website. Copies of the current issue and back issues can be downloaded in both PDF and HTML formats. If you would like to be notified when new issues of the Bulletin are available online, subscribe to the early alert email system at the Bulletin website. The early alert email contains the contents of each new issue along with electronic links to the articles. To receive a printed copy of the Bulletin, subscribe online at the Bulletin website, or contact your local public health unit or the editorial office. eISSN 1834-8610

Website: www.publish.csiro.au/journals/phb Copyright $\odot 2009$ NSW Department of Health 